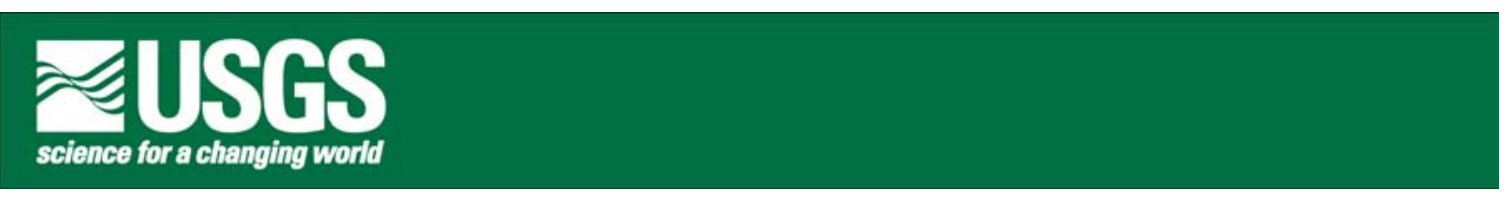

\title{
Geologic database for digital geology of California, Nevada, and Utah - an application of the North American Data Model
}

By David R. Bedford ${ }^{1}$, Steve Ludington ${ }^{1}$, Constance M. Nutt ${ }^{2}$, Paul A. Stone ${ }^{1}$, David M. Miller ${ }^{1}$, Robert J. Miller ${ }^{1}$, David L. Wagner ${ }^{3}$, and George J. Saucedo ${ }^{3}$.

\section{OPEN-FILE REPORT 03-135}

\section{3}

This report is preliminary and has not been reviewed for conformity with U.S. Geological Survey editorial standards or with the North American Stratigraphic Code. Any use of trade, product, or firm names is for descriptive purposes only and does not imply endorsement by the U.S. Government.

This report, identified as "Geologic database for digital geology of California, Nevada, and Utah — an application of the North American Data Model" has been approved for release and publication by the Director of the USGS. Although this database has been subjected to rigorous review and is substantially complete, the USGS reserves the right to revise the data pursuant to further analysis and review. Furthermore, it is released on condition that neither the USGS nor the United States Government may be held liable for any damages resulting from its authorized or unauthorized use.

\section{U.S. DEPARTMENT OF THE INTERIOR U.S. GEOLOGICAL SURVEY}

1 U.S. Geological Survey, 345 Middlefield Road, Menlo Park, CA 94025

2 U.S. Geological Survey, P.O. Box 25046, Denver, CO 80225

3 California Geological Survey, 80-1 K St. MS 12-31, Sacramento, CA 95814 


\section{INTRODUCTION}

The USGS is creating an integrated national database for digital state geologic maps that includes stratigraphic, age, and lithologic information. The majority of the conterminous 48 states have digital geologic base maps available, often at scales of 1:500,000. This product is a prototype, and is intended to demonstrate the types of derivative maps that will be possible with the national integrated database. This database permits the creation of a number of types of maps via simple or sophisticated queries, maps that may be useful in a number of areas, including mineral-resource assessment, environmental assessment, and regional tectonic evolution.

This database is distributed with three main parts: a Microsoft Access 2000 database containing geologic map attribute data, an Arc/Info (Environmental Systems Research Institute, Redlands, California) Export format file containing points representing designation of stratigraphic regions for the Geologic Map of Utah, and an ArcView 3.2 (Environmental Systems Research Institute, Redlands, California) project containing scripts and dialogs for performing a series of generalization and mineral resource queries.

IMPORTANT NOTE: Spatial data for the respective stage geologic maps is not distributed with this report. The digital state geologic maps for the states involved in this report are separate products, and two of them are produced by individual state agencies, which may be legally and/or financially responsible for this data. However, the spatial datasets for maps discussed in this report are available to the public. Questions regarding the distribution, sale, and use of individual state geologic maps should be sent to the respective state agency. We do provide suggestions for obtaining and formatting the spatial data to make it compatible with data in this report. See section 'Obtaining and Formatting Spatial Data'.

The only spatial data distributed with this report is a set of points describing stratigraphic region codes for the Geologic Map of Utah. In the original version of that map (Hintze, 1980), there were separate description of map units and correlation of map units for several regions of the state. A small index map was provided to designate the boundaries of each region. The authors of this report have included these regional descriptions in the database, and have provided suggestions for incorporating these regions into the user-supplied geologic map in the section 'Obtaining and Formatting Spatial Data'. Note that the use of these regional descriptions is not required, but may provide more detailed information to the user.

\section{DATABASE OVERVIEW}

This database is distributed as a Microsoft Access 2000 format database. The tables in the database reflect those described in "DIGITAL GEOLOGIC MAP DATA MODEL, Version 4.3" available at: http://geology.usgs.gov/dm/. This Data Model has also been termed the "North American Data Model Version 4.3", and will be referred to in this text as NADM 4.3. While this is a draft document, it represents a set of proposed standards for the structure and content of digital geologic maps. All background information regarding the intent, format, and contents of this data model should be referred to in the document referenced above. More background information can be found at: http://ncgmp.usgs.gov/ngmdbproject/standards/datamodel/datamodelWG.html and indicated links. 
This database also contains several Microsoft Jet SQL queries that are intended to provide easy user access to common types of geologic information contained in the database. Many of these queries are general use queries that provide lithologic and age information, often involving manipulation of data hierarchies in the data model. Other queries are specific to mineral resource investigations that represent first-cut efforts to demonstrate the usefulness of the data structure.

\section{DATABASE DESCRIPTION}

\section{Database Assumptions}

Version 4.3 of the proposed Geologic Data Model is quite complex and flexible. Due to the lack of available datasets in this format, many assumptions have been included in the database. Many tables are blank or contain minimal information to satisfy the spirit of the Data Model. Furthermore, the data requirements for this data have constrained the use of the Data Model to specific usages of tables or fields within tables.

In many cases, there are one-to-one correlations between records in various tables in the database. Where possible, the ID's that serve as primary keys have remained the same. For instance, in this report there is a one-to-one correspondence between records in the Classification_Object table and the COA table. Matching records between these tables have the same CLASS_OBJ_ID and COA_ID values. To preserve database integrity, the Data_Classification table, which provides for a many-to-many relation between the two tables, is complete.

The NADM 4.3 specifies a compound key between spatial features in a GIS and their attributes in the rest of the database with the Spatial_Obj_ID and Dataset_ID fields to enable each spatial feature to not need to be uniquely identified outside of that dataset. While a good design feature, many GIS packages do not offer the capability to use a compound key, and thus the user would be required to filter through the correct Dataset_ID values before joining or relating to attribute data. This is further complicated by the fact that any spatial feature can belong to multiple classification objects, which essentially creates a three-field compound key based on the Spatial_Obj_ID, Dataset_ID, and Class_Obj_ID fields. What we have done is to uniquely identify each feature in all of the datasets discussed in this report to eliminate the need for further querying. While this is not feasible for very large datasets, users are encouraged to use the same scheme, as discussed below.

Database Tables

A complete listing of database tables and fields is included in Table 1 at the end of this report. For detailed explanations of the structure, relationships, and content descriptions, refer to the NADM 4.3 draft documentation. All of the tables and fields discussed in the data model document are included in this report, including tables that contain no data. This is to facilitate understanding of the complete database structure, future improvements in content, and to support software tools. 
Several tables that are not documented in NADM 4.3 have been added to the database. These tables are used by a beta version of a software product being developed named "GeoMatter," which is intended to facilitate the attribution of geologic maps in NADM 4.3, as well as a version of the NADM put forth by the Canadian Geological Survey, informally dubbed NADM 5.2. Geomatter is currently under development, and is not available for release at this time. NADM 5.2 is also a draft standard that is available on-line at http://cordlink.gsc.nrcan.gc.ca/cordlink1/

One more table has been added to this database by the authors that is not included in NADM 4.3. This table is called 'Comp_Values'. The design of the Data Model allows for multiple rock compositions per a given map unit. The Rock_Composition table allows for the map attributer to provide volumetric percentages as well as the accuracy, or quality, of that percentage that each rock composition contributes to the map unit. In many cases, such information is not given in an existing map Description Of Map Units (DMU). However, the typical nomenclature of a DMU is to give a list of rock compositions in a list of descending contributions. Since this list is inherently qualitative, it may be difficult or impossible to infer a percentage of contribution for each composition. What we have done is to use the attribute 'comp_seq' in the Rock_Composition table to store such information. This field is intended to be an identifier for a unique rock composition for a map unit. We have used the scheme of assigning the first rock composition listed in a DMU a value of 1, and numbering sequential rock compositions in the DMU with sequential comp_seq numbers. In this scheme, one can always retrieve an ordered, relative list of rock_compositions. To facilitate the English language usage of this structure, we have provided the Comp_Values table. It contains the range of comp_seq values in the Rock_Composition table, and English language interpretation of those values. We have adopted the following scheme for descriptions of comp_seq values:

\begin{tabular}{|r|l|}
\hline comp_seq & comp_value \\
\hline 1 & Primary \\
\hline 2 & Secondary \\
\hline 3 & Tertiary \\
\hline 4 & Quaternary \\
\hline 5 & Quinary \\
\hline 6 & Senary \\
\hline 7 & Septenary \\
\hline 8 & Octonary \\
\hline 9 & Nonary \\
\hline 10 & Denary \\
\hline
\end{tabular}


This scheme allows a user to retrieve a textural description of a rock composition's contribution to a map unit. Clearly, these are draft values, and can be changed. They are included to provide access to a ranked list of contributions. There are also many instances where these values would not be appropriate. For instance, given a map unit containing two lithologies (rock compositions) it is impossible to tell if each lithology contributes $50 \%$ to the map unit, or if one lithology contributes an overwhelming amount to the map unit. Likewise, given a large number of rock compositions, it may be impossible to determine if each contributes roughly equal amounts to a map unit, or if some contribute very minor or accessory amounts.

\section{Database Queries}

We have included sets of SQL queries in the database that are meant to be of general geologic usefulness and for particular mineral resource evaluations. These queries are in Microsoft Jet SQL format, which is a variant on the SQL standard. While the datasets for this report are at a smaller scale than most mineral resource assessments, they are included to demonstrate the power of the data structure for that purpose. Care should be taken not to violate the scale constraints on the source data.

Due to the simplicity of classification schemes in this report, the included queries have been separated into component queries. This is due to the fact that there is a one-toone correspondence between entries in the Classification_Object table and entries in the COA table for data in this report. Furthermore, for this report, each Spatial Object (GIS feature) only belongs to one Classification_Object. This means that there is a static relationship between COAs and Spatial Objects. A query can be made to define which Spatial Objects belong to which COAs, which will not change. A further benefit of this is that it speeds up query performance, especially when dealing with ODBC, since the base query, which may return many thousands of records, is only performed once. All the other queries, which can be joined to the base query, return many fewer records, and therefore are more efficient.

The base component for all queries is the query named

'QryGisRockPolyCOAID' since it relates polygonal features in the GIS to COAs that describe rock units. This query returns the Spatial_Obj_ID field, which identifies all GIS features, and the COA_ID field, which identifies all Compound Objects. Because of the numbering scheme of spatial identifiers used in this report, the field Dataset_ID field is not needed in this query, but can be quickly added to the query by the user, if needed.

The use of the base query may vary. It may be used inside a DMBS to link with other queries, or it may be retrieved from the DMBS into GIS software, and directly linked to the GIS layers. The latter method is most likely the most efficient. The results of this query can be joined or linked in GIS software to GIS layers, thereby assigning a COA_ID value to each feature. Results of other queries, that return COA_ID values, can then be joined or linked to the GIS layer or set of features, using the COA_ID field as the key. 


\section{Obtaining and Formatting Spatial Data}

\section{California}

A digital version of the Geologic Map of California is available from the California Geological Survey. There are use constraints and a fee for this dataset.

California Geological Survey, 2000, GIS data for the Geologic Map of California, California Geological Survey CD 2000-007, \$40.

This CD contains a database of geologic units and faults digitized from the 1977 Geologic Map of California by Charles W. Jennings. Files are in both Arc/Info export files (.e00) and MapInfo format. The CD also contains Postscript and Arc/Info plot files, and an Adobe Acrobat image of the map and legend. A planimetric raster base image of the state in TIFF format is included.

The order form is available at:

http://www.consrv.ca.gov/cgs/information/publications/ordering.htm

Or contact:

California Department of Conservation, California Geological Survey

Attn: Publication Sales

1059 Vine Street, Suite 103

Sacramento, CA 95814-0321

Phone: (916) 445-6199

Fax: (916) 324-5644

URL: http://www.consrv.ca.gov/cgs/

Nevada

The digital version of the Nevada State Geologic Map has undergone numerous revisions since it was first published as USGS DDS-2 in 1989. The most recent version is:

Spatial Digital Database for the Geologic Map of Nevada, U.S.G.S. Open-file report 03-066. The map can be downloaded, in Arc-export format, directly from the web at http://geopubs.wr.usgs.gov/open-file/of03-66/

Utah

The Utah Geological Survey has recently published a digital version of the Geologic Map of Utah, which was used for this report; it is available from the Utah Geological Survey for a fee.

Hintze, L.F., Willis, G.C., Laes, D.Y.M., Sprinkel, D.A., and Brown, K.D., 2000, Digital geologic map of Utah, Utah Geological Survey, in cooperation with U.S. Geological Survey, Map 179DM, CD Rom, \$19.95. 
Utah Geological Survey

1594 West North Temple

P.O. Box 146100

Salt Lake City, UT 84114-6100

Phone: (801) 537-3300

Fax: (801) 537-3400

Bookstore (801) 537-3320 or 888-UTAH-MAP (882-4627)

Bookstore email: geostore@state.ut.us

URL: http://mapstore.utah.gov/

Once the spatial data is obtained, it must be formatted to be compatible with the database supplied in this report. Following the translation of the spatial data into an appropriate GIS format, the proper attribute table fields (also known as items, or columns) must be created and populated in order to link to the data in this report. The minimum requirement is the Spatial_Obj_ID field, which stores a unique numeric identifier for each spatial feature. The NADM 4.3 specifies Dataset_ID and Source_ID fields as well. The following is the Arc/Info specification for spatial data attribute tables used in this report, although the user may choose to modify these. Most geologic datasets contain both polygon and line type features, which each are attributed. The NADM 4.3 specifies the same fields regardless of the feature type, but since this report only contains polygon type information, these fields only need to be added to the polygon feature class of each dataset.

\begin{tabular}{|c|c|c|c|}
\hline ITEM NAME & WIDTH & $\underline{\text { OUTPUT }}$ & TYPE \\
\hline SPATIAL OBJ ID & 12 & 12 & $\mathrm{I}$ \\
\hline DATASET_ID & 12 & 12 & I \\
\hline SOURCE ID & 12 & 12 & I \\
\hline
\end{tabular}

Suggested names and specifications for shapefile attribute tables are:

\begin{tabular}{ll} 
FIELD NAME & Data Type \\
\hline SPATIAL_OB & Double \\
DATASET_ID & Double \\
SOURCE_ID & Double
\end{tabular}

Users must then populate the Spatial_Obj_ID field with unique numeric values. At a minimum, the values must be unique to each dataset, although the authors suggest that users populate the field with values that are unique to all of the spatial datasets. The authors have used a scheme that assembles a code for the state (FIPS Code), a code for the layer type, and a unique value for the feature. The first 2 digits from left are state FIPS codes $(\mathrm{CA}=06, \mathrm{NV}=32, \mathrm{UT}=49)$, the digits in space 3-4 from left are a layer identifier (may be the dataset_id or the following: geology polygons $=01$ geology arcs $=02$ ), and the remaining digits are a unique value with 0 's as needed to fill the remaining digits. Because Arc/Info coverages maintain a unique identifier for each feature in the <coverage_name $>$ \# field, the authors recommend using that field as a source for unique identifiers. For example, the California dataset, named 'ca-geol', with under 100,000 features in the geology polygons layer, the following Arc/Info command could be used to calculate unique ID's: 
calculate spatial_obj_id $=060100000+$ ca-geol\# - 1

Similarly, for the geologic lines in California:

calculate spatial_obj_id $=060200000+$ ca-geol\#

Dataset_ID values were constructed similarly, using a combination of the FIPS code, and layer code:

CA Geology Polygons: 601

CA Geology Lines: $\quad 602$

NV Geology Polygons: 3201

NV Geology Lines: $\quad 3202$

UT Geology Polygons: $\quad 4901$

UT Geology Lines: 4902

Source_ID values are not required for the datasets or application in this report, but for data integrity, users are encouraged to calculate these values. The authors have used the state FIPS codes, similar to those used for the Dataset_ID values, although they do not differ based on the layer code, since both line \& polygon feature type layers are created by the same source in this case. Entries for these values are listed below and are included in the Source table.

CA Geology Polygons: $\quad 601$

CA Geology Lines: $\quad 601$

NV Geology Polygons: 3201

NV Geology Lines: 3201

UT Geology Polygons: 4901

UT Geology Lines: $\quad 4901$

To complete the process of combining the spatial data and attribute data, the Spatial_Classification table in this report's database must be completed. This table links the spatial information with the attribute information.

It is important to note that the following changes have been made to the geologic map unit labels identified in the original geologic maps and those presented here. This is important because the geologic map unit labels will serve as a primary key in connecting the individual state map datasets with the attribute database distributed in this report. The following table documents these changes, and users will need to change these values either in the Class_label field of the Classification_Object table or in the map unit label field of the individual state map.

\begin{tabular}{|c|c|}
\hline Original geologic map unit label & Geologic map unit label in this report \\
\hline \multicolumn{2}{|c|}{ GIS Data For The Geologic Map of California } \\
\hline \multicolumn{2}{|l|}{ No changes } \\
\hline \multicolumn{2}{|l|}{ Geologic Map of Nevada } \\
\hline OW (may vary with source) & water \\
\hline blank, or unattributed features & blank \\
\hline
\end{tabular}




\begin{tabular}{|l|l|}
\hline Digital Geologic Map of Utah & \\
\hline PP & $P e P$ \\
\hline Jg & JTr \\
\hline blank, or unattributed features & Blank \\
\hline
\end{tabular}

The following steps will guide the users in assembling the Spatial_Classification table. Because this report focuses on geologic polygon information, this process is only required for the geologic polygon features.

1) Export the Classification_Object table from the database to a format compatible with the user's GIS.

2) Because a map unit code (ie Qal) is being used as a key for joining the two tables, it is important to ensure that the correct values are being joined for datasets from different states that may have the same map unit code. In the event that there are incorrect joins based a map unit code between incorrect states, users can elect to make a selection based on the correct Dataset_ID values, or physically remove incorrect state entries based on the Dataset_ID field, then proceed to the next step. Which method used depends on the users GIS functionality. Note that if users delete entries from the Classification_Object table for a state, they will need to re-export that table from the database in order to retrieve records for the other states.

3) In the user's GIS, join the Class_Label field in the Classification_Object table to the geologic descriptor field in the attribute table for each dataset. This field may have names such as: formation, ptype, or map_unit. Users are encouraged to scan or query the joined table for Class_Obj_ID values from the Classification_Object table that do not match the correct state. These values follow the same scheme as the Dataset_ID values. If incorrect values are found, variations on Step 2 may be required to ensure that only the records for the correct state polygon dataset are being joined to the records for the correct Dataset_ID in the Classification_Object table.

4) The user now has all of the values needed to assemble the Classification_Object table for that state: Spatial_Obj_ID and Dataset_ID from the spatial data, and Class_Obj_ID from the attribute information in this report.

5) The attribute tables for each state map must now be re-imported into Microsoft Access, or the user's database of choice, and appended into the Spatial_Classification table.

a. Export the joined attribute table into a format suitable for Microsoft Access. DBF format is suggested. Note that only the Spatial_Obj_ID, Dataset_ID, and Class_Obj_ID fields are needed.

b. Import each attribute file back into Microsoft Access. Users may want to name each file something like 'spatial_classification_CA' or 'spatial_classification_NV' to keep track of which dataset the file came from.

c. Append each of these tables into the Spatial_Classification table with a series of append queries.

6) Users are encouraged to validate this process by exporting the query 'Spatial_Classification_Check' from Microsoft Access into a format compatible with their GIS. Join the Spatial_Obj_ID fields from that query to the 
Spatial_Obj_ID field in the spatial data. Then query the user's geologic map unit field (ptype, formation, map_unit) for values that are NOT equal to values in the Class_label field from the query.

\section{Utah Region Information}

The original Geologic Map of Utah (Hintze, 1980) was published with eight separate stratigraphic columns and descriptions for differing regions of the state map. These regions were depicted on a very small scale index map in that report. No previously published digital report has included this information. The authors of this report have included these separate stratigraphic descriptions in the databases, for users who may want to use them. However, users will have to perform some extra GIS operations with the data included in this report to incorporate this information.

The map unit descriptions distributed in this report (encapsulated in Classification_Object, COA, Stratigraphic_Age, and Rock_Composition table entries) included all the geologic map units found in the published source map, as well as separate entries for map units that differ regionally. The authors created these map units solely based on the published stratigraphic descriptions. The names of these 'new' map units have been appended with an underscore followed by a code for the region. The following table lists the region codes and their descriptions from the original map.

\begin{tabular}{|l|l|}
\hline Region Code & Description \\
\hline NW & Northwestern Utah \\
\hline LH & Logan-Huntsville Allocthon \\
\hline SL & Salt Lake City-Coalville-Randolph \\
\hline WU & Western Utah \\
\hline CU & Central Utah \\
\hline UM & Uintah Mountains-Uintah Basin \\
\hline SE & Southeastern Utah \\
\hline SW & Southwestern Utah \\
\hline
\end{tabular}

For example, unit $\mathrm{K} 1$ contains entries that apply to the entire state. There are also separate map units named K1_SE, K1_SL, K1_SW, and K1_UM that are slightly modified versions of the state-wide map unit.

This publication is distributed with a spatial dataset containing points that describe the region for each polygon in the user-supplied Digital Geologic Map of Utah (Hintze et al, 2000). These points were created by digitizing the region index map from the original state map, then performing a GIS intersect operation with the map of Hintze, et al. The resulting region boundaries were then removed from the database, resulting in the original state geologic map polygons with a region code. Because the index map was such a small scale, geologic polygons near the region boundaries had to be evaluated and manually assigned a correct region code. Units with ambiguous or indeterminate region assignments were not assigned to a region and therefore are attributed with the state-wide map unit. 
The spatial dataset distributed in this report as an Arc/Info Export format (e00) file named 'ut_regions.e00'. When imported into a spatial dataset (coverage, shapefile, etc), this file will represent one point that falls within each of the geologic polygons from Hintze, et al. The following tables give brief descriptions of the projection and attribute information for this dataset. Formal FGDC metadata is included with this report in the file 'ut_regions.met'.

Projection information for the dataset encoded in 'ut_regions.e00'

\begin{tabular}{|l|l|}
\hline Projection & Geographic \\
\hline Units & Decimal degrees \\
\hline
\end{tabular}

Attribute information for the Arc/Info coverage created from importing 'ut_regions.e00'

\begin{tabular}{|l|c|c|c|c|l|}
\hline Item Name & Width & Output & Type & N. Dec & Description \\
\hline AREA & 4 & 12 & F & 3 & Not used for point features \\
\hline PERIMETER & 4 & 12 & F & 3 & Not used for point features \\
\hline$<$ coverage $>\#$ & 4 & 5 & B & & Unique internal control number \\
\hline$<$ coverage $>$-ID & 4 & 5 & B & & User-assigned identification number \\
\hline REGION & 25 & 25 & C & & Region code \\
\hline
\end{tabular}

Region codes entered into the region field are listed above. Map units or polygons with no regional information are blank.

User's who wish to take advantage of the regional descriptions in this report are suggested to take the following steps to all the regional information to the user-supplied data from Hintze, et al.:

1) Format the dataset of Hintze, et al, using the specifications under section Obtaining and Formatting Spatial Data to ensure that the dataset has Spatial_Object_ID values for each polygon

2) Convert the Arc/Info Export format file, ut_regions.e00 into a suitable format for the GIS in use. The exact procedure for this operation varies with GIS platforms. Translators for this format are available through the USGS Public Domain Software page: http://edcwww.cr.usgs.gov/doc/edchome/ndcdb/public.html

3) If required, project the resultant dataset from Step 2 into a projection that matches the projection used by data from or derived from Hintze, et al.

4) Perform a point-in-polygon analysis with the points from Step 2 and 3, and the geologic polygon dataset from Hintze, et al. This operation should result in the points from Step 2 and 3 now having the attributes (specifically the map unit designator field, and the Spatial_Object_ID field) from polygons from Hintze, et al. Arc/Info Workstation users are suggested to use the identity command. ArcGIS (Environmental Systems Research Institute, Redlands, California) has similar 
capabilities in ArcMap's Geoprocessing Wizard. Most other GIS have similar functions.

5) Users are suggested to add a new text field to the geologic polygon dataset from Hintze, et al. to serve as a field to store the new map unit name (either the state wide map unit, or the regional map unit designator).

6) Join the attribute table from the point dataset created in Step 4 to the geologic polygon attribute table from Hintze, et al., using the Spatial_Object_ID field as the key (common field). The specific techniques vary too widely with GIS platforms to describe, although the technique is commonly called a join. Note that the join need not be a permanent join. This operation will result in the region field from the dataset from Step 2-3 being added to the geologic polygon attribute table.

7) Select features whose region field is NOT blank. Calculate the field added in Step 5 for those selected features to be the concatenation of the attributes stored in the geologic map unit field (originally called formation), a " " character, and the attributes in the region field (called region). A valid SQL phrase, that mimics what many GIS platforms use would be: [formation] \& “" " \& [region]

8) Invert the selection from Step 7 so that features with blank regions attributes are selected. Then calculate the field created in Step 5 to be equal to the geologic map unit field (formation in Hintze, et al.)

9) Users will then need to update the Spatial_Classification table, as described in Steps 1-6 in the above section entitled 'Obtaining and Formatting Spatial Data' with the new relations between Spatial_Obj_ID and Class_Obj_ID. This time join the Class_label field to the field created in Step 5. If users have previously completed those steps, those entries in the Spatial_Classification table for features from the geologic map of Utah will need to be removed prior to updating

\section{ArcView Project Description}

This report is distributed with an ArcView version 3.2 project file and an associated stand-alone executable program that will perform a set of mineral resource and generalization queries on any NADM 4.3 formatted dataset. The project file is named 'wr_mrsa.apr'. The dialog designer ArcView extension is required for this project. The stand-alone executable is a Microsoft Windows executable that reads a query out of the database distributed with this report and displays a hierarchical "tree" view of the lithology hierarchy from this report, including the ability to define a lithologic term and the position (lith_level) of that lithology in the hierarchy. This is useful to envision the entire hierarchy as well as investigating the level of detail desired when performing a lithology generalization.

One of the primary purposes of the ArcView project (herein called 'the project') is to demonstrate the use of geologic information in a standard data format for mineral resources investigations. The project performs three different sets of queries that may be useful for that purpose, two of which allow the user to make three levels of constraints on the query. The project also performs some general-purpose attribute generalization queries. The general algorithms of each query will be discussed below.

Requirements 
The functionality of the ArcView project distributed with this report is based on the avenue scripting language within ArcView GIS. While ArcView 3.x versions exist for PC, Macintosh, and Unix computer systems, the database format distributed in this report is only compatible on computers running Microsoft Windows operating systems. There are translation utilities available to allow the database to be converted to operate under different computing environments. The project was written using ArcView 3.2, and requires the dialog designer extension, which is distributed with ArcView versions 3.1 and higher. Users of ArcView prior to version 3.2 can find utilities to make the project backwards-compatible at the publisher's website, http://www.esri.com

The functionality of the ArcView project in this report also relies on an ODBC connection to the database distributed in this report. The ODBC connection is required to be named 'wr_mrsa'. If this is not an acceptable name, the project can be configured to work with a different name. Two avenue scripts within the project are programmed with the ODBC name. These scripts are named 'sql.fetch' and 'sql.getCOAID'. These two scripts can be edited and recompiled to connect to a different ODBC connection. The scripts are commented to note the value that needs to be changed. Users are strongly discouraged from editing any other scripts distributed in the project.

The project was written so that any dataset in the NADM 4.3 format can be used. The scripts that perform the queries do some error checking to ensure that only NADM 4.3 datasets are used. To do this, the scripts check for the presence of two fields in the attribute tables of each dataset being queried. The first is the dataset_id field. Note that this field only needs to be present in the attribute table of the dataset. The scripts do not perform any operations on values contained, or not contained, in the field. The second required field is the Spatial_Obj_ID field. Due to attribute field name limitations in many dataset formats, the scripts check for 'variants' on the Spatial_Obj_ID fieldname. Valid names for the field are: 'spatial_obj_id', and 'spatial_ob'. Note that the values in this field are critical to maintain links to the correct map units in the database.

\section{Using the ArcView Project}

The ArcView project works on the concept within ArcView of the 'active theme(s)'. Queries will be performed on any and all active (highlighted, or selected) themes that the script can identify as being in the NADM 4.3 format. If no themes are selected, the script will not run. If the script identifies a non-NADM theme in a set of selected themes, then the script will skip that theme. The scripts create a new theme that is a 'virtual copy' of the datasets that it performs a query on. If these virtual datasets are saved within the ArcView project, the queries will be rerun by ArcView when the project is opened again. In order to permanently store the dataset created from a query to a file-based dataset, the theme must manually be written to a shapefile. Consult the ArcView GIS documentation for this procedure.

The project contains two extra menus for view documents. These menus are named 'Minerals Queries' and 'Generalization Queries'. Selecting options in the 'Minerals Queries' menu will bring up a dialog box to perform a variant on the basic query type. For the Potential Skarn and Sediment-Hosted Gold queries, a dialog box will presented that allows the user to specify which subtype of query is desired. Clicking the radio button next to that query description, then pressing the 'Run Query' button will begin the query. Selecting a menu item in the 'Generalization Queries' menu will either bring up a series of dialogs to specify values to generalize with, or will launch the lithology hierarchy browser Windows executable. 
The project is distributed with no data in the project. It is up to the user to add and configure the datasets used by the project. Note that in order for the potential skarn queries to function correctly, the map units for the view containing the datasets must be specified.

The project performs quite a bit of error checking, but cannot anticipate every error. The software is distributed as-is, and the U.S. Geological Survey is not responsible for any problems that may occur.

\section{Discussion of the Queries}

\section{Potential Skarn Queries.}

The basic form of this query is to select all map units from the database that contain carbonate rocks that are adjacent to an intrusive unit. The script run in this query retrieves a query from the database that performs a basic generalization of the primary lithology of all map units and returns those that are carbonate or intrusive (plutonic). The script then selects all of the intrusive rock polygons and performs a GIS 'next to' operation for all units that are immediately next to those intrusive polygons. Finally, all of the carbonate rocks are selected from those polygons next to intrusive rocks, yielding a layer that is all of the carbonate bearing polygons next to an intrusive unit. It is important to note that neither of the queries determines if a plutonic map unit is located next to or near a carbonate unit through depositional or fault contacts.

The second form of this query recognizes the fact that intrusive units do not have to be in immediate contact with carbonate units to produce a skarn deposit. The script performs the same exact query as described above with the exception that units are selected that are within 5 kilometers of any intrusive unit. Views with map units not in meters will use the $5 \mathrm{~km}$ distance equivalent in the view's map units.

The third form of the Potential Skarn Query is a quite complex query and can take significant amounts of computation time. The goal of the query is to ensure that any igneous unit polygon is younger than the carbonate unit polygon that it is within 5 kilometers of. In order for this script to work, it must create 3 temporary datasets in the project's working directory, which is usually the user's 'temp' directory. The script downloads a similar query as describe above from the database, with the exception that the query also returns age information for each map unit. The script then creates a shapefile of all the intrusive bearing polygons, and a shapefile containing all of the carbonate bearing polygons. The script then loops through every feature in the intrusive rocks shapefile, selects all of the polygons in the carbonate shapefile that is within 5 kilometers of that polygon. A comparison of the age of each polygon is performed and a running tally of all features that are older than the intrusive polygon is kept. After all of the polygons in the intrusive shapefile have been analyzed, the script outputs those features that met all of the requirements to a shapefile in the user's working directory. This shapefile will have a 'base' name of 'skarn', followed by a number.

\section{Sediment-hosted Gold Queries}

The general form of the sediment-hosted gold queries is to select map units that contain both mudstones and carbonates, in any amount. A general term for this kind of map unit is 'dirty carbonate.' The query generalizes the lithology hierarchy for both mudstones and carbonates. Mudstones in the hierarchy distributed in this report, which is the standard hierarchy for the datamodel, include the following lithologies: argillite, black shale, claystone, mudstone, oil 
shale, shale, and siltstone. Carbonate lithologies include: carbonate, dolostone (dolomite), and limestone. This is an attributes-based query and does not perform any spatial analysis

The second form of the sediment-hosted gold queries recognizes the prevalence of these deposits in pre-Mesozoic age rocks. The query includes the minimum age of the map unit and only returns those map units that have a minimum stratigraphic age of pre-Mesozoic (250 million years or greater).

The third form of the sediment-hosted gold queries is a further refinement of the knowledge of these deposits in the western United Sates, in that the majority of these deposits are found in dirty carbonates that younger than Ordovician and older than Carboniferous. The query uses minimum stratigraphic age names and their numeric equivalents to return only those map units that have an age range of 360-440 million years.

\section{Acid Neutralization Potential Query}

This query builds on the fact that bedrock can be very important in mitigating problems related to acidic groundwater, and that carbonate rocks can react with acidic waters to increase their $\mathrm{pH}$ to more near-normal values. This query is a first step in determining where that might occur by identifying map units containing carbonate and determining the proportion and type of carbonate in that map unit. The query returns those map units that have either limestone or dolomite as the primary lithology. It also returns those map units that have either limestone or dolomite in any amount except as the primary lithology. The query creates 2 layers for every theme selected, the first containing the primary limestone or dolomite map units, and the other containing the secondary limestone or dolomite map units. Each theme created contains attributes about the type of carbonate contained (limestone or dolomite), which may be useful to determine the relative reactivity of each map unit. This query does not generalize the lithology hierarchy for carbonate rocks, but rather directly selects either limestone or dolomite lithologies. This is by design, recognizing that many map units are attributed simply as 'carbonate', and in many cases it may be necessary to know the type of carbonate.

\section{Generalization Queries}

The ArcView project also contains two general-purpose generalization queries. These queries are demonstrations of typical queries that may be performed on a geologic map database.

\section{Generalization with Age}

Querying for the general age of map units is often a first step in any map preparation or analysis. This query presents the user with the opportunity to quickly generalize a geologic map based on the stratigraphic age information encoded in the database. The query retrieves a specific query from the database that generalizes the stratigraphic age base on two user specifications.

The first choice presented to the user is which age designator to generalize on. Map units in the database have both a minimum and maximum age encoded. For many map units, this choice may have significant effects on the results. Many map units may span significant lengths of time, as well as having varying degrees of accuracy of either knowledge or encoding in either of the ages encoded in the database.

The second choice for the user in this query is the detail in geologic age to generalize to. The choices currently presented to the user are: eon, era, period, subperiod, and epoch. This choice determines the level of detail in age information retrieved from the database. Stratigraphic ages are filtered through the Stratigraphic_Time_Scale and the Stratigraphic_Tree tables, 
which compose the stratigraphic age hierarchy. It is important to note that many map units are encoded with only a basic amount of detail in the stratigraphic age. Queries made on a stratigraphic age classification that are more detailed than what is encoded in the database will return empty, or 'no data' values. While this may be undesirable, it may also be used to qualitatively represent the level of knowledge about a map unit.

Regardless of the choices made by the user, the queries return both the encoded minimum and maximum age names for each map unit. The query also returns the generalized age as specified by the user's choices. This is to aid in the use of this query for further analysis.

Generalization with Lithology

Another important piece of information in any geologic map analysis is determining what lithologies are present in a given map unit. This query allows the user to retrieve from the database the primary lithology of all map units, generalizing those lithologies to a given lith_level, which is an indicator of the position of the lithology in the lithology hierarchy. The user is presented with a list of lith_level values, and query returns both the original map unit primary lithology (in the lith_class field) and the generalized lithology (in the lithology field) at the specified lith level. As with the Stratigraphic Age generalization query, map units with lith_class values that are lower (more general) than the specified lith_level will return no data (empty) values.

To help visualize the lithology hierarchy, as well as to provide definitions and lith_level values for those terms, the authors have included a 32-bit MS Windows executable program (lithtree.exe) with this report. This program reads the hierarchy from the database and presents it to the user in a 'tree' form similar to that of a directory structure. User's may click on a lithology term and view the definition and lith_level by clicking on the 'define' button. The program can be run by its self, and is also available from the 'Generalization Queries' menu in the ArcView project. When used in conjunction with the ArcView project, the user may wish to explore the lithology hierarchy in order to determine a suitable lith_level to perform a lithology generalization query with. 
Table 1: Description of tables contained in the database for this report

\begin{tabular}{|c|c|c|c|c|}
\hline Name & Type & Width & $\begin{array}{l}\text { Usage For This } \\
\text { Publication }\end{array}$ & Description \\
\hline Cartographic_Object & Table & $\mathrm{N} / \mathrm{A}$ & $\begin{array}{l}\text { Minimally used to } \\
\text { support GeoMatter }\end{array}$ & $\begin{array}{l}\text { The Cartographic Object Table symbolizes map } \\
\text { objects that are defined in the Classification Object } \\
\text { Table. }\end{array}$ \\
\hline class_obj_id & $\begin{array}{l}\text { Long } \\
\text { Integer }\end{array}$ & 4 & & $\begin{array}{l}\text { A unique identifier for each object or category of } \\
\text { objects described and symbolized in a map legend }\end{array}$ \\
\hline class_seq & $\begin{array}{l}\text { Long } \\
\text { Integer }\end{array}$ & 4 & Default Value of 0 & $\begin{array}{l}\text { A number representing the drawing sequence of the } \\
\text { individual patterns which make up a symbol, a value } \\
\text { of } 1 \text { is the bottom pattern, } 2 \text { is the next up, etc. }\end{array}$ \\
\hline cart_desc & Text & 255 & $\begin{array}{c}\text { same value as } \\
\text { class_label that it } \\
\text { supports in the } \\
\text { Classification_Object } \\
\text { Table }\end{array}$ & Description of the pattern \\
\hline cart_sym_type & Text & 50 & $\begin{array}{l}\text { Default Value of } \\
\text { Polygon }\end{array}$ & Specifies the type of symbol as: area, line, or point \\
\hline cart_sym_table & Text & 50 & $\begin{array}{l}\text { Default Value of } \\
\text { Standard }\end{array}$ & Name of a symbol table \\
\hline cart_sym & $\begin{array}{l}\text { Long } \\
\text { Integer }\end{array}$ & 4 & All values 1001 & $\begin{array}{l}\text { The symbol number from the table specified in } \\
\text { cart_sym_table }\end{array}$ \\
\hline cart_color_table & Text & 50 & $\begin{array}{l}\text { Default Value of } \\
<\text { Symbol table }>\end{array}$ & Name of a color table \\
\hline cart_color & $\begin{array}{l}\text { Long } \\
\text { Integer }\end{array}$ & 4 & $\begin{array}{l}\text { same value as } \\
\text { class_obj_id }\end{array}$ & $\begin{array}{l}\text { The color number from the table specified in } \\
\text { cart_color_table }\end{array}$ \\
\hline Class_Tree & Table & $\mathrm{N} / \mathrm{A}$ & $\begin{array}{l}\text { Minimally used, no } \\
\text { hierarchical } \\
\text { information stored, one } \\
\text { entry for each } \\
\text { Class_obj_id }\end{array}$ & $\begin{array}{l}\text { The Class Tree Table is used to store information } \\
\text { about parent-child relationships between units that } \\
\text { occur in the Classification Object Table. }\end{array}$ \\
\hline scheme_id & $\begin{array}{l}\text { Long } \\
\text { Integer }\end{array}$ & 4 & & $\begin{array}{l}\text { Identification number, unique to a classification } \\
\text { scheme, used to link a classification scheme with its } \\
\text { name and source }\end{array}$ \\
\hline class_obj_id & $\begin{array}{l}\text { Long } \\
\text { Integer }\end{array}$ & 4 & $\begin{array}{l}\text { class obj_id = } \\
\text { class_obj_parent }\end{array}$ & $\begin{array}{l}\text { A unique identifier for each category of objects } \\
\text { described and symbolized in the map legend. It is } \\
\text { the link to the Classification Object Table }\end{array}$ \\
\hline class_obj_parent & $\begin{array}{l}\text { Long } \\
\text { Integer }\end{array}$ & 4 & $\begin{array}{l}\text { class obj_id = } \\
\text { class_obj_parent }\end{array}$ & $\begin{array}{l}\text { A unique identifier for a second record in the } \\
\text { Classification Object Table which is the parent of the } \\
\text { Classification identified in class_obj_id }\end{array}$ \\
\hline Classification_Name & Table & $\mathrm{N} / \mathrm{A}$ & $\begin{array}{l}\text { Minimally used, one } \\
\text { entry per state }\end{array}$ & $\begin{array}{l}\text { The Classification Name Table is used for naming } \\
\text { classification schemes and tying them back to an } \\
\text { original source. }\end{array}$ \\
\hline class_scheme_id & $\begin{array}{l}\text { Long } \\
\text { Integer }\end{array}$ & 4 & & $\begin{array}{l}\text { Identification number; unique to a classification } \\
\text { scheme; used to link all objects in a classification } \\
\text { scheme with a name and source }\end{array}$ \\
\hline class_scheme_name & Text & 255 & & Descriptive name for the classification scheme \\
\hline source_id & $\begin{array}{l}\text { Long } \\
\text { Integer }\end{array}$ & 4 & & $\begin{array}{l}\text { Unique identification number of an information } \\
\text { source }\end{array}$ \\
\hline Classification_Object & Table & $\mathrm{N} / \mathrm{A}$ & Fully Used & $\begin{array}{l}\text { The Classification Object Table is used to define the } \\
\text { objects that are to appear on a map and therefore, } \\
\text { on the map legend. }\end{array}$ \\
\hline
\end{tabular}




\begin{tabular}{|c|c|c|c|c|}
\hline class_obj_id & $\begin{array}{l}\text { Long } \\
\text { Integer }\end{array}$ & 4 & $\begin{array}{c}\text { stores classification } \\
\text { number }\end{array}$ & $\begin{array}{l}\text { A unique identifier for each object or category of } \\
\text { objects described and symbolized in a map legend }\end{array}$ \\
\hline class_group & Text & 50 & default value of 1 & $\begin{array}{l}\text { Used to group similar objects within the map legend. } \\
\text { On paper maps these terms are the headings for } \\
\text { various sections of the legend }\end{array}$ \\
\hline class_label & Text & 50 & $\begin{array}{c}\text { label as appears on } \\
\text { map (ie 'Jgr') }\end{array}$ & $\begin{array}{l}\text { The character symbol for the item on the legend. For } \\
\text { a rock unit, this would be the unit label, such as } \\
\text { TKgr }\end{array}$ \\
\hline class_name & Text & 255 & $\begin{array}{l}\text { label as appears on } \\
\text { map (ie 'Jgr') }\end{array}$ & $\begin{array}{l}\text { The name assigned to this legend item. For a rock } \\
\text { unit, this might be the unit name, such as Pike's } \\
\text { Peak Granite, or alluvium. For a structural unit, it } \\
\text { might be a formal name, such as San Andreas Fault, } \\
\text { or an informal name, such as normal fault. }\end{array}$ \\
\hline class_desc & Text & 255 & $\begin{array}{l}\text { Description of Map } \\
\text { Unit }\end{array}$ & $\begin{array}{l}\text { An English language description of the legend object } \\
\text { or group of objects. For objects or groups of objects } \\
\text { which are not defined in the Compound Object } \\
\text { Archive, this is the descriptive text which would } \\
\text { appear on a map legend }\end{array}$ \\
\hline Classification_Scheme & Table & $\mathrm{N} / \mathrm{A}$ & $\begin{array}{l}\text { Minimally used, one } \\
\text { scheme per state }\end{array}$ & $\begin{array}{l}\text { The Classification Scheme Table provides the } \\
\text { correlation between the Source Table and the } \\
\text { Legend's Classification Object Table. }\end{array}$ \\
\hline source_id & $\begin{array}{l}\text { Long } \\
\text { Integer }\end{array}$ & 4 & & $\begin{array}{l}\text { Unique identification number of an information } \\
\text { source }\end{array}$ \\
\hline class_obj_id & $\begin{array}{l}\text { Long } \\
\text { Integer }\end{array}$ & 4 & & $\begin{array}{l}\text { A unique identifier for each category of objects } \\
\text { described and symbolized in the map legend. It is } \\
\text { the link to the Classification Object Table }\end{array}$ \\
\hline class_scheme_id & $\begin{array}{l}\text { Long } \\
\text { Integer }\end{array}$ & 4 & & $\begin{array}{l}\text { Identification number, unique to a classification } \\
\text { scheme, used to link a classification scheme with its } \\
\text { name and source }\end{array}$ \\
\hline class_seq & $\begin{array}{l}\text { Long } \\
\text { Integer }\end{array}$ & 4 & Default Value of 0 & $\begin{array}{l}\text { A number defining the sequential position of the } \\
\text { object in the legend, within its classification group } \\
\text { (see Classification Object Table) }\end{array}$ \\
\hline disp_priority & $\begin{array}{l}\text { Long } \\
\text { Integer }\end{array}$ & 4 & Default Value of 0 & $\begin{array}{l}\text { A priority number, which allows the user to specify } \\
\text { the order in which objects are drawn when the map } \\
\text { is displayed. Objects with larger numbers are drawn } \\
\text { on top of, and may hide, objects with smaller } \\
\text { numbers }\end{array}$ \\
\hline disp_visibility & Text & 1 & Default Value of $\mathrm{T}$ & $\begin{array}{l}\text { A toggle, which indicates whether the object is } \\
\text { displayed in the legend or remains hidden from view } \\
\text { when the legend is displayed }\end{array}$ \\
\hline COA & Table & $\mathrm{N} / \mathrm{A}$ & Fully Used & $\begin{array}{l}\text { COA Table is the central table used to describe } \\
\text { Compound Objects. Primary use of the COA Table } \\
\text { is to specify which type of unit is being described, } \\
\text { therefore, which additional tables should be } \\
\text { consulted for the remainder of the description of the } \\
\text { unit }\end{array}$ \\
\hline coa_id & $\begin{array}{l}\text { Long } \\
\text { Integer }\end{array}$ & 4 & unique COA number & $\begin{array}{l}\text { Unique identification number of a unit in the } \\
\text { Compound Object Archive }\end{array}$ \\
\hline coa_name & Text & 50 & $\begin{array}{l}\text { label as appears on } \\
\text { map (ie 'Jgr') }\end{array}$ & $\begin{array}{l}\text { The name of the unit in the Compound Object } \\
\text { Archive }\end{array}$ \\
\hline coa_type & Text & 50 & $\begin{array}{l}\text { value defined in } \\
\text { COA_Type table }\end{array}$ & $\begin{array}{l}\text { Type of Compound Object (Rock Unit, Structure, } \\
\text { etc.) }\end{array}$ \\
\hline coa_desc & Text & 255 & $\begin{array}{c}\text { General description of } \\
\text { the map unit }\end{array}$ & A text description of the Compound Object \\
\hline source_id & $\begin{array}{l}\text { Long } \\
\text { Integer }\end{array}$ & 4 & Source Identifier & $\begin{array}{l}\text { Unique identification number of an information } \\
\text { source }\end{array}$ \\
\hline COA_Relation & Table & $\mathrm{N} / \mathrm{A}$ & Not Used & $\begin{array}{l}\text { The COA Relation Table is used to store information } \\
\text { about the relationships between objects that occur in } \\
\text { the COA Table. }\end{array}$ \\
\hline
\end{tabular}




\begin{tabular}{|c|c|c|c|c|}
\hline rel_id & $\begin{array}{l}\text { Long } \\
\text { Integer }\end{array}$ & 4 & & $\begin{array}{l}\text { Unique identification number for a record in this } \\
\text { table }\end{array}$ \\
\hline coa_id & $\begin{array}{l}\text { Long } \\
\text { Integer }\end{array}$ & 4 & & $\begin{array}{l}\text { Unique identification number of a unit in the } \\
\text { Compound Object Archive }\end{array}$ \\
\hline rel_coa_id & $\begin{array}{l}\text { Long } \\
\text { Integer }\end{array}$ & 4 & & $\begin{array}{l}\text { Unique identification number of a second unit in the } \\
\text { COA Table to which the first object is related in } \\
\text { some fashion }\end{array}$ \\
\hline rel_desc & Text & 50 & & Text description of the relationship \\
\hline relation & Text & 50 & & $\begin{array}{l}\text { A broad category of temporal and structural } \\
\text { relationships between units. This information may } \\
\text { allow for refinement of age, structural, or spatial } \\
\text { relationships }\end{array}$ \\
\hline Coa_Relation_Type & Table & $\mathrm{N} / \mathrm{A}$ & Not Used & $\begin{array}{l}\text { (DM 5.2)The COA Rel Type table is a lookup table } \\
\text { for containing possible types of relations between } \\
\text { COAs; e.g. overlies, contemporaneous, etc. }\end{array}$ \\
\hline coa_relation & Text & 50 & & $\begin{array}{l}\text { A broad category of temporal, structural or other } \\
\text { relationships between units. }\end{array}$ \\
\hline rel_type_desc & Text & 50 & & A text description of the relationship type. \\
\hline COA_Tree & Table & $\mathrm{N} / \mathrm{A}$ & $\begin{array}{l}\text { Minimally used, each } \\
\text { COA is a child of } \\
\text { 'Universe' and to itself }\end{array}$ & $\begin{array}{l}\text { The COA Tree Table is used to store information } \\
\text { about parent-child relationships between units that } \\
\text { occur in the COA Table. }\end{array}$ \\
\hline coa_id & $\begin{array}{l}\text { Long } \\
\text { Integer }\end{array}$ & 4 & & $\begin{array}{l}\text { Unique identification number of a unit in the } \\
\text { Compound Object Archive }\end{array}$ \\
\hline parent_id & $\begin{array}{l}\text { Long } \\
\text { Integer }\end{array}$ & 4 & & $\begin{array}{l}\text { Unique identification number of a second unit in the } \\
\text { COA Table which is the parent of the unit identified } \\
\text { in coa_id }\end{array}$ \\
\hline COA_Type & Table & $\mathrm{N} / \mathrm{A}$ & Standard Domain & $\begin{array}{l}\text { (DM 5.2) The COA Type table is a lookup table } \\
\text { which contains a list of the valid COA table types }\end{array}$ \\
\hline coa_type & Text & 50 & & The type of COA \\
\hline coa_type_desc & Text & 50 & & A text description of the COA type. \\
\hline coa_table & Text & 50 & & $\begin{array}{l}\text { The name of the table corresponding to a coa type: } \\
\text { e.g. for rock_unit its 'Rock Unit', for 'meta_facies' its } \\
\text { 'Meta. Facies'. }\end{array}$ \\
\hline COA_Valid_Desc & Table & $\mathrm{N} / \mathrm{A}$ & Standard Domain & $\begin{array}{l}\text { (DM5.2)The COA Valid Desc table contains a list of } \\
\text { valid descriptions for each COA table: e.g. a rock } \\
\text { unit may be described by 'Struc Type' or 'Rock } \\
\text { Comp' or 'Geochron Age' or 'Strat Age'. }\end{array}$ \\
\hline coa_type & Text & 50 & & The type of COA \\
\hline desc_type & Text & 50 & & The desc_type identifies a type of description table \\
\hline Color & Table & $\mathrm{N} / \mathrm{A}$ & $\begin{array}{l}\text { Minimally used to } \\
\text { support GeoMatter }\end{array}$ & $\begin{array}{l}\text { The Color Table is a compilation of definitions of } \\
\text { symbol colors. }\end{array}$ \\
\hline cart_color_table & Text & 50 & $\begin{array}{l}\text { Default value of } \\
<\text { Symbol table }>\end{array}$ & Name of a color table \\
\hline cart_color & $\begin{array}{l}\text { Long } \\
\text { Integer }\end{array}$ & 4 & $\begin{array}{l}\text { same as class_obj_id } \\
\text { it supports }\end{array}$ & $\begin{array}{l}\text { The unique number for a specific color within a color } \\
\text { table }\end{array}$ \\
\hline CMYK & Text & 50 & not used & $\begin{array}{l}\text { Definition of color in cyan-magenta-yellow-black } \\
\text { coordinates }\end{array}$ \\
\hline RGB & Text & 50 & used & Definition of color in red-green-blue coordinates \\
\hline color_desc & Text & 255 & $\begin{array}{l}\text { same as class_label } \\
\text { that it supports }\end{array}$ & Description of the color and suggested uses \\
\hline
\end{tabular}




\begin{tabular}{|c|c|c|c|c|}
\hline Comp_Values & Table & N/A & & $\begin{array}{l}\text { Added Table to support a ranked qualitative list of a } \\
\text { rock compositions contribution to a rock unit COA. }\end{array}$ \\
\hline comp_seq & $\begin{array}{l}\text { Long } \\
\text { Integer }\end{array}$ & 4 & & $\begin{array}{l}\text { A numeric comp_seq value as found in the } \\
\text { Rock_Composition Table }\end{array}$ \\
\hline comp_value & Text & 50 & & $\begin{array}{l}\text { An English Language definition of a comp_seq } \\
\text { number. }\end{array}$ \\
\hline Data_Classification & Table & N/A & $\begin{array}{l}\text { Fully Used, most } \\
\text { COA_ID = } \\
\text { CLASS_OBJ_ID }\end{array}$ & $\begin{array}{l}\text { The Data Classification Table is a correlation table } \\
\text { that joins the Classification Object Table to the } \\
\text { Compound Object Archive (COA Table). }\end{array}$ \\
\hline class_obj_id & $\begin{array}{l}\text { Long } \\
\text { Integer }\end{array}$ & 4 & & $\begin{array}{l}\text { A unique identifier for each object or category of } \\
\text { objects described and symbolized in the map legend }\end{array}$ \\
\hline coa_id & $\begin{array}{l}\text { Long } \\
\text { Integer }\end{array}$ & 4 & & $\begin{array}{l}\text { Unit identifier which is the key attribute of the COA } \\
\text { Table }\end{array}$ \\
\hline vol_percent & Integer & 2 & Default Value of 100 & $\begin{array}{l}\text { Estimated volume percent an individual unit in the } \\
\text { Compound Object Archive comprises of the entire } \\
\text { Classification Object }\end{array}$ \\
\hline vol_quality & Integer & 2 & Default Value of 100 & $\begin{array}{l}\text { Quality of the volume percent estimate (entered as: } \\
+-\mathrm{nn} \%)\end{array}$ \\
\hline data_seq & $\begin{array}{l}\text { Long } \\
\text { Integer }\end{array}$ & 4 & Default Value of 0 & $\begin{array}{l}\text { Specifies the order in which individual units in the } \\
\text { Compound Object Archive should appear in a } \\
\text { composite map legend item (a classification object } \\
\text { that includes more than one COA unit) }\end{array}$ \\
\hline Dataset & Table & N/A & $\begin{array}{l}\text { System table used by } \\
\text { GeoMatter }\end{array}$ & $\begin{array}{l}\text { (DM 5.2) The dataset table contains information } \\
\text { about a specific encapsulated set of data. In most } \\
\text { GIS this will correspond to a map layer }\end{array}$ \\
\hline dataset_id & $\begin{array}{l}\text { Long } \\
\text { Integer }\end{array}$ & 4 & & $\begin{array}{l}\text { A unique numeric id for the dataset. In most GIS } \\
\text { systems the dataset will be a layer and this id would } \\
\text { represent a unique number for a layer. }\end{array}$ \\
\hline dataset_name & Text & 100 & & The name for the dataset. \\
\hline dataset_type & Text & 50 & & $\begin{array}{l}\text { The type of dataset = \{ "point", "line", "polygon", } \\
\text { "raster" }\}\end{array}$ \\
\hline dataset_filename & Text & 100 & & The full path and filename location of the dataset. \\
\hline dataset_soid_field & Text & 50 & & $\begin{array}{l}\text { The name of the attribute in the dataset containing } \\
\text { the spatial object id. }\end{array}$ \\
\hline dataset_dsid_field & Text & 50 & & $\begin{array}{l}\text { The name of the attribute in the dataset containing } \\
\text { the dataset id. }\end{array}$ \\
\hline subj_id & $\begin{array}{l}\text { Long } \\
\text { Integer }\end{array}$ & 4 & & $\begin{array}{l}\text { The id of a subject best associated with the dataset } \\
\text { (map layer). }\end{array}$ \\
\hline Dataset_Query & Table & N/A & $\begin{array}{l}\text { System table used by } \\
\text { GeoMatter }\end{array}$ & $\begin{array}{l}\text { (DM 5.2) The Dataset Query table lists and } \\
\text { describes the queries that can be applied to a map } \\
\text { layer within a web module. }\end{array}$ \\
\hline dataset_id & $\begin{array}{l}\text { Long } \\
\text { Integer }\end{array}$ & 4 & & Unique id for the dataset to which a query applies. \\
\hline query_name & Text & 100 & & $\begin{array}{l}\text { The name of query as it appears in the database } \\
\text { system. }\end{array}$ \\
\hline query_title & Text & 50 & & The title of the query. \\
\hline query_desc & Memo & 0 & & $\begin{array}{l}\text { A text description of the query as it is to be displayed } \\
\text { to a user. }\end{array}$ \\
\hline query_heading & Text & 50 & & $\begin{array}{l}\text { A heading under which the query is grouped; for } \\
\text { constructing a list that contains two levels: the } \\
\text { headings at one level and associated queries under } \\
\text { them at another level. }\end{array}$ \\
\hline query_type & Text & 50 & & $\begin{array}{l}\text { The type of query. Queries are applied to at most } \\
\text { one layer and one web site module. Query types } \\
\text { include: map_reclass, map_select, map_text, } \\
\text { map_image, etc. }\end{array}$ \\
\hline
\end{tabular}




\begin{tabular}{|c|c|c|c|c|}
\hline Desc_Type & Table & N/A & $\begin{array}{c}\text { System table used by } \\
\text { GeoMatter }\end{array}$ & $\begin{array}{l}\text { (DM 5.2) The Desc Type table is a lookup table } \\
\text { which contains a list of the valid Description table } \\
\text { types }\end{array}$ \\
\hline desc_type & Text & 50 & & The description table type \\
\hline desc_type_desc & Text & 50 & & Description \\
\hline desc_table & Text & 50 & & $\begin{array}{l}\text { The name of the description table represented by } \\
\text { the desc_type. }\end{array}$ \\
\hline Form & Table & $\mathrm{N} / \mathrm{A}$ & $\begin{array}{c}\text { Standard Domain, Not } \\
\text { Used }\end{array}$ & None \\
\hline form & Text & 100 & & None \\
\hline Form_id & $\begin{array}{l}\text { Long } \\
\text { Integer }\end{array}$ & 4 & & None \\
\hline form_level & $\begin{array}{l}\text { Long } \\
\text { Integer }\end{array}$ & 4 & & None \\
\hline form_desc & Text & 255 & & None \\
\hline Form_Tree & Table & N/A & $\begin{array}{l}\text { Standard Hierarchy } \\
\text { Table, Not Used }\end{array}$ & None \\
\hline Form_id & $\begin{array}{l}\text { Long } \\
\text { Integer }\end{array}$ & 4 & & None \\
\hline parent_id & $\begin{array}{l}\text { Long } \\
\text { Integer }\end{array}$ & 4 & & None \\
\hline Formal_Unit & Table & $\mathrm{N} / \mathrm{A}$ & Not Used & $\begin{array}{l}\text { The Formal Unit Table is used to store information } \\
\text { about the formal definition of a unit. }\end{array}$ \\
\hline Coa_id & $\begin{array}{l}\text { Long } \\
\text { Integer }\end{array}$ & 4 & & $\begin{array}{l}\text { Unique identification number of a unit in the } \\
\text { Compound Object Archive }\end{array}$ \\
\hline name & Text & 255 & & Formal name of the compound object \\
\hline type_section & Text & 255 & & Location of a defining type section or area \\
\hline Fossil & Table & $\mathrm{N} / \mathrm{A}$ & Not Used & $\begin{array}{l}\text { The Fossil Table is another example of the type of } \\
\text { table that could be built into the archive to store non- } \\
\text { structural information collected from a single site. }\end{array}$ \\
\hline fossil_id & $\begin{array}{l}\text { Long } \\
\text { Integer }\end{array}$ & 4 & & $\begin{array}{l}\text { A unique identifier for a single record in the Fossil } \\
\text { Table }\end{array}$ \\
\hline Spatial_obj_id & $\begin{array}{l}\text { Long } \\
\text { Integer }\end{array}$ & 4 & & $\begin{array}{l}\text { A unique identifier for each object in an individual } \\
\text { data set, or layer }\end{array}$ \\
\hline dataset_id & $\begin{array}{l}\text { Long } \\
\text { Integer }\end{array}$ & 4 & & $\begin{array}{l}\text { Unique identification number for each data set or } \\
\text { layer in a GIS }\end{array}$ \\
\hline site_name & Text & 50 & & $\begin{array}{l}\text { Name or field number associated with the sample } \\
\text { site. }\end{array}$ \\
\hline fossil_name & Text & 50 & & Name of the identified fossil \\
\hline site_label & Text & 50 & & $\begin{array}{l}\text { A label to associate with the map symbol, if it is } \\
\text { different than the site_name }\end{array}$ \\
\hline min_strat_name & Text & 50 & & $\begin{array}{l}\text { The minimum time-stratigraphic age selected from } \\
\text { the Stratigraphic Time Scale Table. }\end{array}$ \\
\hline max_strat_name & Text & 50 & & $\begin{array}{l}\text { The maximum time-stratigraphic age selected from } \\
\text { the Stratigraphic Time Scale Table. }\end{array}$ \\
\hline comment & Text & 255 & & A text description of the fossil \\
\hline source_id & $\begin{array}{l}\text { Long } \\
\text { Integer }\end{array}$ & 4 & & $\begin{array}{l}\text { Unique identification number of an information } \\
\text { source }\end{array}$ \\
\hline
\end{tabular}




\begin{tabular}{|c|c|c|c|c|}
\hline Geochronological_Age & Table & N/A & Not Used & $\begin{array}{l}\text { The Geochronologic Age Table is used for storing } \\
\text { geochronologic age data for rock units. }\end{array}$ \\
\hline Coa_id & $\begin{array}{l}\text { Long } \\
\text { Integer }\end{array}$ & 4 & & $\begin{array}{l}\text { Unique identification number of a unit in the } \\
\text { Compound Object Archive }\end{array}$ \\
\hline Chron_seq & $\begin{array}{l}\text { Long } \\
\text { Integer }\end{array}$ & 4 & & $\begin{array}{l}\text { Record identifier for a specific age determination for } \\
\text { the unit identified by the coa_id. }\end{array}$ \\
\hline chron_method & Text & 255 & & Analytical method used to obtain the age \\
\hline sample_material & Text & 255 & & A description of the material sampled \\
\hline Chron_date & Double & 8 & & Geochronologic age, in millions of years \\
\hline chron_err_plus & Double & 8 & & $\begin{array}{l}\text { The positive error for the geochronologic age, in } \\
\text { millions of years }\end{array}$ \\
\hline chron_err_minus & Double & 8 & & $\begin{array}{l}\text { The negative error for the geochronologic age, in } \\
\text { millions of years }\end{array}$ \\
\hline comment & Text & 255 & & $\begin{array}{l}\text { Additional comments concerning this age } \\
\text { determination }\end{array}$ \\
\hline source_id & $\begin{array}{l}\text { Long } \\
\text { Integer }\end{array}$ & 4 & & $\begin{array}{l}\text { Unique identification number of an information } \\
\text { source }\end{array}$ \\
\hline LithoForm & Table & $\mathrm{N} / \mathrm{A}$ & Not Used & (DM 5.2) Contains form or morphology terms. \\
\hline Litho_form & Text & 50 & & A form or morphology term. \\
\hline Form_desc & Text & 255 & & A text description of the form. \\
\hline source_id & $\begin{array}{l}\text { Long } \\
\text { Integer }\end{array}$ & 4 & & $\begin{array}{l}\text { A reference to the source (in the metadata) of the } \\
\text { lithologic term. This could refer to a specific map, } \\
\text { report or author. }\end{array}$ \\
\hline Lithology & Table & N/A & $\begin{array}{l}\text { Standard Domain, } \\
\text { 'Version 6.0' }\end{array}$ & $\begin{array}{l}\text { The Lithology Table is used as a look-up table for } \\
\text { lithologic terms used in the Rock Composition Table }\end{array}$ \\
\hline lith_class & Text & 255 & & $\begin{array}{l}\text { A predefined hierarchical list of lithologic terms used } \\
\text { for classifying rock compositions. }\end{array}$ \\
\hline Lith_id & $\begin{array}{l}\text { Long } \\
\text { Integer }\end{array}$ & 4 & & $\begin{array}{l}\text { A unique identifier for the lithologic term which is } \\
\text { used in the Lithology Tree table to store parent-child } \\
\text { relations }\end{array}$ \\
\hline lith_level & $\begin{array}{l}\text { Long } \\
\text { Integer }\end{array}$ & 4 & & $\begin{array}{l}\text { A numeric value for the level in the hierarchy of } \\
\text { lithologic terms. }\end{array}$ \\
\hline lith_desc & Text & 255 & & An English language definition of the lithologic term. \\
\hline Lithology_Tree & Table & N/A & $\begin{array}{l}\text { Standard Hierarchy } \\
\text { Table, 'Version 6.0' }\end{array}$ & $\begin{array}{l}\text { The Lithology Tree Table is used to store } \\
\text { information about parent-child relations between } \\
\text { lithologies that occur in the Lithology Table. }\end{array}$ \\
\hline Lith_id & $\begin{array}{l}\text { Long } \\
\text { Integer }\end{array}$ & 4 & & $\begin{array}{l}\text { A unique identifier for a lithologic term from the } \\
\text { Lithology Table }\end{array}$ \\
\hline parent_id & $\begin{array}{l}\text { Long } \\
\text { Integer }\end{array}$ & 4 & & $\begin{array}{l}\text { A unique identifier for a second lithologic term from } \\
\text { the Lithology Table which is the parent of the first } \\
\text { term }\end{array}$ \\
\hline Metamorphic_Facies & Table & N/A & Not Used & $\begin{array}{l}\text { The Metamorphic Facies Table is used to store } \\
\text { information about metamorphic facies units }\end{array}$ \\
\hline coa_id & $\begin{array}{l}\text { Long } \\
\text { Integer }\end{array}$ & 4 & & $\begin{array}{l}\text { Unique identification number of a unit in the } \\
\text { Compound Object Archive }\end{array}$ \\
\hline Meta_grade & Text & 50 & & $\begin{array}{l}\text { The metamorphic grade of the metamorphic facies, } \\
\text { which should be selected }\end{array}$ \\
\hline Organization & Table & N/A & Not Used & $\begin{array}{l}\text { The Organization Table is used to provide a full, } \\
\text { formal name for organizations (such as U.S. } \\
\text { Geological Survey) in addition to the shorter, } \\
\text { abbreviated identifier (USGS) that is used in the } \\
\text { Source Table. }\end{array}$ \\
\hline
\end{tabular}




\begin{tabular}{|c|c|c|c|c|}
\hline Org_id & Text & 50 & & Unique organization identifier \\
\hline org_name & Text & 255 & & Full organization name \\
\hline Projection & Table & N/A & Fully Used & $\begin{array}{l}\text { The Projection Table is used to store all of the } \\
\text { parameters necessary to fully specify the map } \\
\text { projection for each source of information. }\end{array}$ \\
\hline Prj_id & Text & 50 & & $\begin{array}{l}\text { A unique identification code assigned to a projection } \\
\text { record }\end{array}$ \\
\hline prj_type & Text & 50 & & Type of projection; e.g. UTM, TM, Mercator, etc. \\
\hline zone & Integer & 2 & & The grid zone specification for a UTM projection \\
\hline ellipsoid & Text & 50 & & The name of the ellipsoid used \\
\hline Scale_factor & Double & 8 & & The scale factor for the projection \\
\hline units & Text & 50 & & The units; e.g. feet, survey feet, meters, etc. \\
\hline origin_lat & Double & 8 & & $\begin{array}{l}\text { The latitude of the origin of the projection in decimal } \\
\text { degrees }\end{array}$ \\
\hline Origin_long & Double & 8 & & $\begin{array}{l}\text { The longitude of the origin of the projection in } \\
\text { decimal degrees }\end{array}$ \\
\hline False_east & Double & 8 & & The offset in the $x$ direction in projection units. \\
\hline False_north & Double & 8 & & The offset in the $y$ direction in projection units. \\
\hline parallel_1 & Double & 8 & & $\begin{array}{l}\text { The first standard parallel for a Lambert projection in } \\
\text { decimal degrees }\end{array}$ \\
\hline parallel_2 & Double & 8 & & $\begin{array}{l}\text { The second standard parallel for a Lambert } \\
\text { projection in decimal degrees }\end{array}$ \\
\hline radius & Double & 8 & & $\begin{array}{l}\text { The radius associated with some polar-type } \\
\text { projections, in kilometers }\end{array}$ \\
\hline cen_meridian & Double & 8 & & $\begin{array}{l}\text { The longitude of the central meridian of the } \\
\text { projection in decimal degrees }\end{array}$ \\
\hline RelatedSource & Table & N/A & Not Used & $\begin{array}{l}\text { The Related Source Table is used to document } \\
\text { relationships between various sources of } \\
\text { information. }\end{array}$ \\
\hline Source1_id & $\begin{array}{l}\text { Long } \\
\text { Integer }\end{array}$ & 4 & & $\begin{array}{l}\text { Unique identification number of an information } \\
\text { source }\end{array}$ \\
\hline Source2_id & $\begin{array}{l}\text { Long } \\
\text { Integer }\end{array}$ & 4 & & $\begin{array}{l}\text { Unique identification number of a second information } \\
\text { source }\end{array}$ \\
\hline Source_relation & Text & 50 & & $\begin{array}{l}\text { Specifies the type of relationship source1 has with } \\
\text { source2 }\end{array}$ \\
\hline Rock_Composition & Table & $\mathrm{N} / \mathrm{A}$ & Fully Used & $\begin{array}{l}\text { The Rock Composition Table is used to define a } \\
\text { single composition within a rock unit. }\end{array}$ \\
\hline Coa_id & $\begin{array}{l}\text { Long } \\
\text { Integer }\end{array}$ & 4 & & $\begin{array}{l}\text { Unique identification number of a unit in the } \\
\text { Compound Object Archive }\end{array}$ \\
\hline Comp_seq & $\begin{array}{l}\text { Long } \\
\text { Integer }\end{array}$ & 4 & $\begin{array}{c}1=\text { primary, } 2= \\
\text { secondary, } 3=\text { tertiary, } \\
\text { etc in Description of } \\
\text { Map Units }\end{array}$ & $\begin{array}{l}\text { Unique ID of a composition within a rock unit. Also } \\
\text { indicates the sequence number for displaying } \\
\text { descriptive information about this composition within } \\
\text { a rock unit description. Compositions are normally } \\
\text { sequenced from most abundant to least abundant }\end{array}$ \\
\hline rock_name & Text & 255 & $\begin{array}{c}\text { name of rock as it } \\
\text { appears in Description } \\
\text { of Map Units }\end{array}$ & $\begin{array}{l}\text { A free-text attribute for storing the map author's } \\
\text { preferred complete name for the rock composition }\end{array}$ \\
\hline lith_class & Text & 50 & $\begin{array}{c}\text { value of equivalent } \\
\text { lithology from Lithology } \\
\text { Table }\end{array}$ & $\begin{array}{l}\text { A lithologic classification term selected from those } \\
\text { available in the Lithology Table }\end{array}$ \\
\hline lith_form & Text & 50 & Not Used (empty field) & $\begin{array}{l}\text { A form or morphology classification term selected } \\
\text { from those available in a Form Table }\end{array}$ \\
\hline
\end{tabular}




\begin{tabular}{|c|c|c|c|c|}
\hline vol_percent & Integer & 2 & $\begin{array}{c}\text { Default Value of } 0 \text {, see } \\
\text { comp_seq for } \\
\text { assumed volumetric } \\
\text { contribution }\end{array}$ & $\begin{array}{l}\text { An estimate of the volume percent of the } \\
\text { composition within the rock unit }\end{array}$ \\
\hline vol_quality & Integer & 2 & Default Value of 0 & $\begin{array}{l}\text { Quality of the volume percent estimate (entered as: } \\
+- \text { nn \%) }\end{array}$ \\
\hline mineralogy_desc & Text & 255 & Not Used (empty field) & $\begin{array}{l}\text { A mineral modifier associated with the rock name, or } \\
\text { description of the mineralogy of the composition }\end{array}$ \\
\hline Color_desc & Text & 255 & Not Used (empty field) & $\begin{array}{l}\text { A description of the color or colors of the } \\
\text { composition }\end{array}$ \\
\hline Texture_desc & Text & 255 & Not Used (empty field) & A description of the texture of the composition \\
\hline alteration_desc & Text & 255 & Not Used (empty field) & $\begin{array}{l}\text { A description of any alteration associated with the } \\
\text { composition }\end{array}$ \\
\hline description & Text & 255 & Not Used (empty field) & $\begin{array}{l}\text { A text description of this composition. Intended to be } \\
\text { read by people, this is where a long, detailed map } \\
\text { legend description would be stored. }\end{array}$ \\
\hline Rock_Unit & Table & $\mathrm{N} / \mathrm{A}$ & Not Used & $\begin{array}{l}\text { The Rock Unit Table is central to organization of the } \\
\text { description of rock map units. The table is used to } \\
\text { assign a rank to each unit and as a correlation table } \\
\text { between the COA Table and descriptive records in } \\
\text { the Age and Composition Table }\end{array}$ \\
\hline coa_id & $\begin{array}{l}\text { Long } \\
\text { Integer }\end{array}$ & 4 & & $\begin{array}{l}\text { Unique identification number of a unit in the } \\
\text { Compound Object Archive }\end{array}$ \\
\hline rock_rank & Text & 50 & & $\begin{array}{l}\text { A keyword defining the lithostratigraphic level or } \\
\text { rank of the defined unit }\end{array}$ \\
\hline min_thick & $\begin{array}{l}\text { Long } \\
\text { Integer }\end{array}$ & 4 & & Minimum thickness of the rock unit, in meters \\
\hline max_thick & $\begin{array}{l}\text { Long } \\
\text { Integer }\end{array}$ & 4 & & Maximum thickness of the rock unit, in meters \\
\hline typ_thick & $\begin{array}{l}\text { Long } \\
\text { Integer }\end{array}$ & 4 & & $\begin{array}{l}\text { Typical, or average thickness of the rock unit, in } \\
\text { meters }\end{array}$ \\
\hline thick_qual & $\begin{array}{l}\text { Long } \\
\text { Integer }\end{array}$ & 4 & & $\begin{array}{l}\text { Quality of the typical thickness estimate as a percent } \\
\text { of the typical thickness (entered as: +- nn \%) }\end{array}$ \\
\hline Rock_Unit_Rank & Table & $\mathrm{N} / \mathrm{A}$ & Not Used & $\begin{array}{l}\text { The Rock Unit Rank Table is used as a look-up table } \\
\text { to correlate the rank, given in the Rock Unit Table as } \\
\text { a word, with a numeric level number. }\end{array}$ \\
\hline rock_rank & Text & 50 & & $\begin{array}{l}\text { A keyword defining the lithostratigraphic level or } \\
\text { rank of the defined unit }\end{array}$ \\
\hline rock_level & $\begin{array}{l}\text { Long } \\
\text { Integer }\end{array}$ & 4 & & A number indicating the relative rank. \\
\hline SOA & Table & N/A & Not Used & $\begin{array}{l}\text { The SOA (Singular Object Archive) associates a } \\
\text { specific spatial feature (from the GIS) to the } \\
\text { description specific to its occurrence. }\end{array}$ \\
\hline spatial_obj_id & $\begin{array}{l}\text { Long } \\
\text { Integer }\end{array}$ & 4 & & $\begin{array}{l}\text { A unique identifier of each feature in an individual } \\
\text { GIS data layer/coverage/file. }\end{array}$ \\
\hline dataset_id & $\begin{array}{l}\text { Long } \\
\text { Integer }\end{array}$ & 4 & & $\begin{array}{l}\text { The unique id of the specific GIS dataset: } \\
\text { layer/file/coverage. }\end{array}$ \\
\hline desc_type & Text & 50 & & The description table \\
\hline desc_id & $\begin{array}{l}\text { Long } \\
\text { Integer }\end{array}$ & 4 & & $\begin{array}{l}\text { The unique identifier of a description within a } \\
\text { specific description table. }\end{array}$ \\
\hline SOAValidDesc & Table & $\mathrm{N} / \mathrm{A}$ & $\begin{array}{l}\text { System table used by } \\
\text { GeoMatter }\end{array}$ & $\begin{array}{l}\text { (DM5.2)The SOA Valid Desc table contains a list of } \\
\text { valid descriptions for each SOA table }\end{array}$ \\
\hline
\end{tabular}




\begin{tabular}{|c|c|c|c|c|}
\hline desc_type & Text & 50 & & The desc_type identifies a type of description table \\
\hline Source & Table & N/A & Fully Used & $\begin{array}{l}\text { The Source Table contains reference information for } \\
\text { all maps that are original sources for geologic } \\
\text { objects in the map archive. }\end{array}$ \\
\hline source_id & $\begin{array}{l}\text { Long } \\
\text { Integer }\end{array}$ & 4 & & Unique identification number \\
\hline org_id & Text & 50 & & $\begin{array}{l}\text { Unique organization identifier for an information } \\
\text { source }\end{array}$ \\
\hline source_author & Text & 255 & & List of information source authors \\
\hline source_date & $\begin{array}{l}\text { Medium } \\
\text { Date }\end{array}$ & 8 & & Year of information source publication or creation \\
\hline source_title & Text & 255 & & Title of information source \\
\hline pub_edition & Text & 255 & & Publication edition of a published information source \\
\hline pub_series & Text & 255 & & $\begin{array}{l}\text { Publication series name of a published information } \\
\text { source }\end{array}$ \\
\hline pub_issue & Text & 255 & & Issue identification of a published information source \\
\hline pub_place & Text & 255 & & Place of publication \\
\hline pub_contact & Text & 255 & & Contact for information about the source \\
\hline source_scale & $\begin{array}{l}\text { Long } \\
\text { Integer }\end{array}$ & 4 & & Scale of source map (denominator of scale fraction) \\
\hline source_resolution & $\begin{array}{l}\text { Long } \\
\text { Integer }\end{array}$ & 4 & & Resolution of digital source map, in meters \\
\hline prj_id & Text & 50 & & $\begin{array}{l}\text { An identification code linking to the projection } \\
\text { definition in the projection table }\end{array}$ \\
\hline max_lat & Double & 8 & & Northern limit of map in decimal degrees \\
\hline min_lat & Double & 8 & & Southern limit of map in decimal degrees \\
\hline max_long & Single & 4 & & Eastern limit of map in decimal degrees \\
\hline min_long & Double & 8 & & Western limit of map in decimal degrees \\
\hline url & Text & 255 & & $\begin{array}{l}\text { World Wide Web address for the organization that } \\
\text { published the source }\end{array}$ \\
\hline comment & Text & 255 & & Additional information about the source \\
\hline source_contribution & Text & 255 & & $\begin{array}{l}\text { The contribution made by this source to an object } \\
\text { referencing this source; e.g. if the source is } \\
\text { documenting a change to a geologic object on a } \\
\text { map, then this field would record the nature of the } \\
\text { modification }\end{array}$ \\
\hline SourceDataset & Table & $\mathrm{N} / \mathrm{A}$ & $\begin{array}{c}\text { System table used by } \\
\text { GeoMatter }\end{array}$ & $\begin{array}{l}\text { (DM 5.2) The SourceDataset table correlates } \\
\text { sources to datasets, usually for 'Map' sources. }\end{array}$ \\
\hline source_id & $\begin{array}{l}\text { Long } \\
\text { Integer }\end{array}$ & 4 & & The unique id of the source. \\
\hline dataset_id & $\begin{array}{l}\text { Long } \\
\text { Integer }\end{array}$ & 4 & & The unique id of the dataset. \\
\hline disp_priority & $\begin{array}{l}\text { Long } \\
\text { Integer }\end{array}$ & 4 & & $\begin{array}{l}\text { An integer representing the display sequence priority } \\
\text { of a dataset -- usually for 'layer' datasets where } \\
\text { feature level display priority cannot be assigned. }\end{array}$ \\
\hline disp_visibility & $\begin{array}{l}\text { Long } \\
\text { Integer }\end{array}$ & 4 & & $\begin{array}{l}\text { An integer representing the visibility of a dataset= } \\
\text { on/OFF. }\end{array}$ \\
\hline SourceType & Table & $\mathrm{N} / \mathrm{A}$ & $\begin{array}{c}\text { System table used by } \\
\text { GeoMatter }\end{array}$ & $\begin{array}{l}\text { A lookup table containing the types of possible } \\
\text { sources: map, image, project and text. }\end{array}$ \\
\hline source_type & Text & 50 & & The type of source: 'map', 'image', 'text' or 'project'. \\
\hline source_type_desc & Text & 150 & & A text description of the source type. \\
\hline
\end{tabular}




\begin{tabular}{|c|c|c|c|c|}
\hline Spatial_Classification & Table & N/A & Fully Used & $\begin{array}{l}\text { The Spatial Classification Table is a correlation table } \\
\text { that joins the GIS tables of the Spatial Object } \\
\text { Archive to the Classification Object Table of the map } \\
\text { Legend. }\end{array}$ \\
\hline spatial_obj_id & $\begin{array}{l}\text { Long } \\
\text { Integer }\end{array}$ & 4 & & $\begin{array}{l}\text { A unique identifier for each object in an individual } \\
\text { data set, or layer }\end{array}$ \\
\hline dataset_id & $\begin{array}{l}\text { Long } \\
\text { Integer }\end{array}$ & 4 & & $\begin{array}{l}\text { Unique identification number for each data set or } \\
\text { layer in a GIS }\end{array}$ \\
\hline class_obj_id & $\begin{array}{l}\text { Long } \\
\text { Integer }\end{array}$ & 4 & & $\begin{array}{l}\text { A unique identifier for each object or category of } \\
\text { objects described and symbolized in a map legend }\end{array}$ \\
\hline Spatial_Object & Table & N/A & Not Used & None Given \\
\hline spatial_obj_id & $\begin{array}{l}\text { Long } \\
\text { Integer }\end{array}$ & 4 & & $\begin{array}{l}\text { A unique identifier for each object in an individual } \\
\text { data set, or layer }\end{array}$ \\
\hline dataset_id & $\begin{array}{l}\text { Long } \\
\text { Integer }\end{array}$ & 4 & & $\begin{array}{l}\text { Unique identification number for each data set or } \\
\text { layer in a GIS }\end{array}$ \\
\hline source_id & $\begin{array}{l}\text { Long } \\
\text { Integer }\end{array}$ & 4 & & $\begin{array}{l}\text { Unique identification number of an information } \\
\text { source }\end{array}$ \\
\hline Spatial_Object_Age & Table & $N / A$ & Not Used & $\begin{array}{l}\text { The Spatial Object Age Table is used to attach } \\
\text { geochronologic ages to individual spatial objects. }\end{array}$ \\
\hline spatial_obj_id & $\begin{array}{l}\text { Long } \\
\text { Integer }\end{array}$ & 4 & & $\begin{array}{l}\text { A unique identifier for each object in an individual } \\
\text { data set, or layer }\end{array}$ \\
\hline dataset_id & $\begin{array}{l}\text { Long } \\
\text { Integer }\end{array}$ & 4 & & $\begin{array}{l}\text { Unique identification number for each data set or } \\
\text { layer in a GIS }\end{array}$ \\
\hline coa_id & $\begin{array}{l}\text { Long } \\
\text { Integer }\end{array}$ & 4 & & $\begin{array}{l}\text { Unit identifier which is the key attribute of the COA } \\
\text { Table }\end{array}$ \\
\hline chron_seq & $\begin{array}{l}\text { Long } \\
\text { Integer }\end{array}$ & 4 & & $\begin{array}{l}\text { Record identifier for a specific age determination } \\
\text { within the Geochron Age Table for the unit identified } \\
\text { by the coa_id. }\end{array}$ \\
\hline site_name & Text & 50 & & $\begin{array}{l}\text { Name or field number associated with the sample } \\
\text { site. }\end{array}$ \\
\hline Spatial_Object_Composition & Table & N/A & Not Used & $\begin{array}{l}\text { The Spatial Object Composition Table is used to } \\
\text { define the composition breakdown of individual map } \\
\text { objects, where it is known. }\end{array}$ \\
\hline spatial_obj_id & $\begin{array}{l}\text { Long } \\
\text { Integer }\end{array}$ & 4 & & $\begin{array}{l}\text { A unique identifier for each object in an individual } \\
\text { data set, or layer }\end{array}$ \\
\hline dataset_id & $\begin{array}{l}\text { Long } \\
\text { Integer }\end{array}$ & 4 & & $\begin{array}{l}\text { Unique identification number for each data set or } \\
\text { layer in a GIS }\end{array}$ \\
\hline coa_id & $\begin{array}{l}\text { Long } \\
\text { Integer }\end{array}$ & 4 & & $\begin{array}{l}\text { Unit identifier which is the key attribute of the COA } \\
\text { Table }\end{array}$ \\
\hline comp_seq & $\begin{array}{l}\text { Long } \\
\text { Integer }\end{array}$ & 4 & & $\begin{array}{l}\text { Identification number of a single composition } \\
\text { description within a rock unit (see Rock Composition } \\
\text { Table) or zero to indicate entire unit }\end{array}$ \\
\hline vol_percent & Integer & 2 & & $\begin{array}{l}\text { Estimated volume percent that the individual unit or } \\
\text { composition in the Compound Object Archive } \\
\text { comprises of the single spatial object }\end{array}$ \\
\hline vol_quality & Integer & 2 & & $\begin{array}{l}\text { Quality of the volume percent estimate (entered as: } \\
+-\mathrm{nn} \%)\end{array}$ \\
\hline source_id & $\begin{array}{l}\text { Long } \\
\text { Integer }\end{array}$ & 4 & & $\begin{array}{l}\text { Unique identification number of an information } \\
\text { source }\end{array}$ \\
\hline Spatial_Object_Name & Table & $\mathrm{N} / \mathrm{A}$ & Not Used & $\begin{array}{l}\text { The Spatial Object Name Table is used to apply } \\
\text { names (or any other text) to a single map object. }\end{array}$ \\
\hline spatial_obj_id & $\begin{array}{l}\text { Long } \\
\text { Integer }\end{array}$ & 4 & & $\begin{array}{l}\text { A unique identifier for each object in an individual } \\
\text { data set, or layer }\end{array}$ \\
\hline
\end{tabular}




\begin{tabular}{|c|c|c|c|c|}
\hline dataset_id & $\begin{array}{l}\text { Long } \\
\text { Integer }\end{array}$ & 4 & & $\begin{array}{l}\text { Unique identification number for each data set or } \\
\text { layer in a GIS }\end{array}$ \\
\hline name & Text & 50 & & $\begin{array}{l}\text { Name to be attached to an individual point, line, or } \\
\text { polygon. For example the name of a pluton or a fault }\end{array}$ \\
\hline source_id & $\begin{array}{l}\text { Long } \\
\text { Integer }\end{array}$ & 4 & & $\begin{array}{l}\text { Unique identification number of an information } \\
\text { source }\end{array}$ \\
\hline Stratigraphic_Age & Table & N/A & $\begin{array}{l}\text { Fully Used, one entry } \\
\text { per appropriate COA }\end{array}$ & $\begin{array}{l}\text { The Stratigraphic Age Table is used for storing } \\
\text { information about the time-stratigraphic age of the } \\
\text { unit. }\end{array}$ \\
\hline coa_id & $\begin{array}{l}\text { Long } \\
\text { Integer }\end{array}$ & 4 & & $\begin{array}{l}\text { Unique identification number of a unit in the } \\
\text { Compound Object Archive }\end{array}$ \\
\hline strat_seq & $\begin{array}{l}\text { Long } \\
\text { Integer }\end{array}$ & 4 & & $\begin{array}{l}\text { Record identifier for a specific time interval for the } \\
\text { unit identified by the coa_id. }\end{array}$ \\
\hline Min_strat_name & Text & 50 & & $\begin{array}{l}\text { The minimum time-stratigraphic age selected from } \\
\text { the Stratigraphic Time Scale Table }\end{array}$ \\
\hline max_strat_name & Text & 50 & & $\begin{array}{l}\text { The maximum time-stratigraphic age selected from } \\
\text { the Stratigraphic Time Scale Table }\end{array}$ \\
\hline min_source_id & $\begin{array}{l}\text { Long } \\
\text { Integer }\end{array}$ & 4 & & $\begin{array}{l}\text { Unique identification number of an information } \\
\text { source for the minimum age reference }\end{array}$ \\
\hline max_source_id & $\begin{array}{l}\text { Long } \\
\text { Integer }\end{array}$ & 4 & & $\begin{array}{l}\text { Unique identification number of an information } \\
\text { source for the maximum age reference }\end{array}$ \\
\hline Stratigraphic_Rank & Table & N/A & Not Used & $\begin{array}{l}\text { The Stratigraphic Rank Table is a look-up table, } \\
\text { which provides a numeric value for the time- } \\
\text { stratigraphic rank key words used in the } \\
\text { Stratigraphic Time Scale Table. }\end{array}$ \\
\hline Strat_rank & Text & 50 & & $\begin{array}{l}\text { A keyword representing the rank of the time- } \\
\text { stratigraphic term. }\end{array}$ \\
\hline strat_level & $\begin{array}{l}\text { Long } \\
\text { Integer }\end{array}$ & 4 & & $\begin{array}{l}\text { A numeric value for the level in the hierarchy of time- } \\
\text { stratigraphic terms. }\end{array}$ \\
\hline Stratigraphic_Time_Scale & Table & $\mathrm{N} / \mathrm{A}$ & $\begin{array}{l}\text { Standard Domain, } \\
\text { slightly modified for } \\
\text { missing Ages }\end{array}$ & $\begin{array}{l}\text { The Stratigraphic Time Scale Table is used as a } \\
\text { look-up table for time-stratigraphic intervals which } \\
\text { are used to define the maximum and minimum } \\
\text { stratigraphic age of units defined in the Rock Unit } \\
\text { Table. }\end{array}$ \\
\hline strat_id & $\begin{array}{l}\text { Long } \\
\text { Integer }\end{array}$ & 4 & & A unique identifier for the strat_name \\
\hline strat_name & Text & 255 & & The time-stratigraphic name for the time interval \\
\hline Strat_rank & Text & 10 & & $\begin{array}{l}\text { A keyword representing the rank of the time- } \\
\text { stratigraphic term. Must be defined in the } \\
\text { Stratigraphic Rank table }\end{array}$ \\
\hline min_strat_age & Double & 8 & & Minimum numerical age, in millions of years \\
\hline max_strat_age & Double & 8 & & Maximum numerical age, in millions of years \\
\hline min_source_id & $\begin{array}{l}\text { Long } \\
\text { Integer }\end{array}$ & 4 & $\begin{array}{l}\text { Values of } 1 \text { signify } \\
\text { values added for this } \\
\text { report }\end{array}$ & $\begin{array}{l}\text { Unique identification number of an information } \\
\text { source for the minimum age reference }\end{array}$ \\
\hline max_source_id & $\begin{array}{l}\text { Long } \\
\text { Integer }\end{array}$ & 4 & $\begin{array}{l}\text { Values of } 1 \text { signify } \\
\text { values added for this } \\
\text { report }\end{array}$ & $\begin{array}{l}\text { Unique identification number of an information } \\
\text { source for the maximum age reference }\end{array}$ \\
\hline Stratigraphic_Tree & Table & $\mathrm{N} / \mathrm{A}$ & $\begin{array}{l}\text { Standard Hierarchy } \\
\text { Table, slightly modified } \\
\text { for missing Ages }\end{array}$ & $\begin{array}{l}\text { The Stratigraphic Tree Table is used to store } \\
\text { information about parent-child relationships between } \\
\text { time-stratigraphic intervals that occur in the } \\
\text { Stratigraphic Time Scale Table. }\end{array}$ \\
\hline
\end{tabular}




\begin{tabular}{|c|c|c|c|c|}
\hline strat_id & $\begin{array}{l}\text { Long } \\
\text { Integer }\end{array}$ & 4 & & $\begin{array}{l}\text { A unique identifier for a time-stratigraphic interval } \\
\text { from the Stratigraphic Time Scale table }\end{array}$ \\
\hline parent_id & $\begin{array}{l}\text { Long } \\
\text { Integer }\end{array}$ & 4 & & $\begin{array}{l}\text { A unique identifier for a second time-stratigraphic } \\
\text { interval from the Stratigraphic Time Scale table } \\
\text { which is a parent of the first interval }\end{array}$ \\
\hline Structural_Measurement & Table & $\mathrm{N} / \mathrm{A}$ & Not Used & $\begin{array}{l}\text { The Structural Measurement Table represents an } \\
\text { example of a table for storing information generally } \\
\text { depicted on a map as point objects. }\end{array}$ \\
\hline struct_id & $\begin{array}{l}\text { Long } \\
\text { Integer }\end{array}$ & 4 & & $\begin{array}{l}\text { A unique identifier for a record in the Structural } \\
\text { Measurement Table }\end{array}$ \\
\hline Spatial_obj_id & $\begin{array}{l}\text { Long } \\
\text { Integer }\end{array}$ & 4 & & $\begin{array}{l}\text { A unique identifier for each object in an individual } \\
\text { data set, or layer }\end{array}$ \\
\hline dataset_id & $\begin{array}{l}\text { Long } \\
\text { Integer }\end{array}$ & 4 & & $\begin{array}{l}\text { Unique identification number for each data set or } \\
\text { layer in a GIS }\end{array}$ \\
\hline site_name & Text & 50 & & $\begin{array}{l}\text { Name or field number associated with the sample } \\
\text { site. }\end{array}$ \\
\hline feature_type & Text & 50 & & $\begin{array}{l}\text { The type of structural measurement (bedding, fold } \\
\text { axis, foliation, etc.) }\end{array}$ \\
\hline Strike_trend & Integer & 2 & & $\begin{array}{l}\text { The azimuth direction of the strike or trend of the } \\
\text { structural measurement, in degrees (for planar } \\
\text { features use the right-hand rule for strike direction; } \\
\text { for linear features, the trend is down the plunge } \\
\text { direction) }\end{array}$ \\
\hline dip_plunge & Integer & 2 & & $\begin{array}{l}\text { The dip or plunge angle of the structural } \\
\text { measurement, in degrees }\end{array}$ \\
\hline dip_direction & Integer & 2 & & $\begin{array}{l}\text { The azimuth direction of the dip of a planar feature } \\
\text { projected to the horizontal, in degrees. This direction } \\
\text { is equal to the strike direction plus } 90 \text { degrees }\end{array}$ \\
\hline planar_linear & Text & 1 & & $\begin{array}{l}\text { A toggle, which indicates whether the measurement } \\
\text { is for a planar or a linear feature }\end{array}$ \\
\hline comment & Text & 255 & & A text description of the structural measurement. \\
\hline source_id & $\begin{array}{l}\text { Long } \\
\text { Integer }\end{array}$ & 4 & & $\begin{array}{l}\text { Unique identification number of an information } \\
\text { source }\end{array}$ \\
\hline Structural_Type & Table & $\mathrm{N} / \mathrm{A}$ & & $\begin{array}{l}\text { The Structural Type Table contains the attributes of } \\
\text { various types of structural features. }\end{array}$ \\
\hline struct_typ_id & $\begin{array}{l}\text { Long } \\
\text { Integer }\end{array}$ & 4 & & $\begin{array}{l}\text { Unique identifier for each combination of type and } \\
\text { modifier }\end{array}$ \\
\hline type & Text & 50 & & A major category of types of geologic structures \\
\hline modifier & Text & 50 & & $\begin{array}{l}\text { A modifier to the major structure type specifying the } \\
\text { specific type of structure }\end{array}$ \\
\hline struct_type_desc & Text & 255 & & A short description defining the structure type \\
\hline Structure & Table & $\mathrm{N} / \mathrm{A}$ & & $\begin{array}{l}\text { The Structure Table links the COA Table to the } \\
\text { Structural Type Table. }\end{array}$ \\
\hline coa_id & $\begin{array}{l}\text { Long } \\
\text { Integer }\end{array}$ & 4 & & $\begin{array}{l}\text { Unique identification number of a unit in the } \\
\text { Compound Object Archive }\end{array}$ \\
\hline struct_typ_id & $\begin{array}{l}\text { Long } \\
\text { Integer }\end{array}$ & 4 & & $\begin{array}{l}\text { Unique identification number of a record in the } \\
\text { Structural Type table }\end{array}$ \\
\hline loc_accuracy & Text & 50 & & Locational or positional accuracy of the structure \\
\hline confidence & Text & 50 & & $\begin{array}{l}\text { A measure of confidence that the geologic feature } \\
\text { exists in the field or has been identified correctly in } \\
\text { the field (i.e. Matti and others, 1997) }\end{array}$ \\
\hline Symbol & Table & N/A & Standard Domain & $\begin{array}{l}\text { The Symbol Table represents the various symbol } \\
\text { tables that are used within each individual GIS. }\end{array}$ \\
\hline
\end{tabular}




\begin{tabular}{|c|c|c|c|c|}
\hline cart_sym_type & Text & 50 & & Specifies the type of symbol as: area, line, or point \\
\hline cart_sym_table & Text & 50 & & Name of a symbol table \\
\hline cart_sym & $\begin{array}{l}\text { Long } \\
\text { Integer }\end{array}$ & 4 & & $\begin{array}{l}\text { The number of a specific symbol pattern within a } \\
\text { symbol table }\end{array}$ \\
\hline symbol_desc & Text & 255 & & $\begin{array}{l}\text { Description of the symbol pattern and suggested } \\
\text { uses }\end{array}$ \\
\hline SYSALIAS & Table & N/A & $\begin{array}{l}\text { System table used by } \\
\text { GeoMatter }\end{array}$ & $\begin{array}{l}\text { (DM 5.2) SYSALIAS contains a list of tables and } \\
\text { fields whose contents are to be substituted by the } \\
\text { contents of an alias table and field in the display of } \\
\text { data }\end{array}$ \\
\hline TABLENAME & Text & 50 & & $\begin{array}{l}\text { The name of the table containing the field to be } \\
\text { aliased. }\end{array}$ \\
\hline FIELDNAME & Text & 50 & & $\begin{array}{l}\text { The name of the field whose contents are to be } \\
\text { aliased; i.e. displayed in text vs. numeric form. }\end{array}$ \\
\hline ALIASTABLE & Text & 50 & & The name of the table containing the alias field. \\
\hline ALIASFIELD & Text & 50 & & $\begin{array}{l}\text { The name of the field whose value will be used as } \\
\text { the alias in the display. }\end{array}$ \\
\hline KEYFIELD & Text & 50 & & None Given \\
\hline SYSCARTO & Table & N/A & $\begin{array}{l}\text { System table used by } \\
\text { GeoMatter }\end{array}$ & $\begin{array}{l}\text { (DM 5.2) Documents the system specific } \\
\text { symbolization parameters; in this case oriented to } \\
\text { ESRl's MapObjects. }\end{array}$ \\
\hline cart_sym_table & Text & 50 & & $\begin{array}{l}\text { The name of the symbol library that the symbol } \\
\text { belongs to. }\end{array}$ \\
\hline cart_sym & $\begin{array}{l}\text { Long } \\
\text { Integer }\end{array}$ & 4 & & The index of the symbol within the symbol library. \\
\hline cart_sym_type & Text & 10 & & None Given \\
\hline cart_MOdesc & Memo & 0 & & $\begin{array}{l}\text { An implementation specific description of the } \\
\text { symbol; in this case, for ESRI's MapObjects } \\
\text { software. }\end{array}$ \\
\hline cart_MOvers & Text & 10 & & The version number of ESRI's MapObjects software. \\
\hline SYSDIX & Table & N/A & $\begin{array}{l}\text { System table used by } \\
\text { GeoMatter }\end{array}$ & $\begin{array}{l}\text { (DM 5.2) The Tree Manager manages look-up tables } \\
\text { that are lists and hierarchies. A general mechanism } \\
\text { is introduced that allows a hierarchy (or a list) to be } \\
\text { built from the database, and an item(s) to be } \\
\text { selected from a hierarchical list and returned }\end{array}$ \\
\hline TABLENAME & Text & 50 & & $\begin{array}{l}\text { TableName: the name of the table containing a field } \\
\text { linked to a look-up list. }\end{array}$ \\
\hline FIELDNAME & Text & 100 & & $\begin{array}{l}\text { FieldName: the names of the fields linked to the } \\
\text { look-up table. }\end{array}$ \\
\hline DIXTABLE & Text & 100 & & $\begin{array}{l}\text { DixTable: the name of the look-up table. If one more } \\
\text { than one table is listed then the tables are (outer) } \\
\text { joined on primary key (DixKey). }\end{array}$ \\
\hline DIXKEY & Text & 100 & & $\begin{array}{l}\text { DixKey: the primary key(s) for the dix lookup tables; } \\
\text { used to (outer) join the DixTables. }\end{array}$ \\
\hline DIXDISPLAYFIELD & Text & 100 & & $\begin{array}{l}\text { DixDisplayField: the names of dictionary fields } \\
\text { whose values are displayed in the interface }\end{array}$ \\
\hline DIXRETURNFIELD & Text & 100 & & $\begin{array}{l}\text { DixReturnField: the names of the dictionary fields } \\
\text { whose values are returned from the look-up into the } \\
\text { FieldName. }\end{array}$ \\
\hline DIXEDIT & Text & 10 & & $\begin{array}{l}\text { DixEdit: yes/no toggle indicating whether the } \\
\text { dictionary can be edited }\end{array}$ \\
\hline DIXVALIDATION & Text & 10 & & $\begin{array}{l}\text { DixValidation: a yes/no toggle that determines } \\
\text { whether the FieldName contents MUST come from } \\
\text { the look-up. }\end{array}$ \\
\hline DIXRANKFIELD & Text & 100 & & $\begin{array}{l}\text { DixRankField: the name of field(s) that specifies the } \\
\text { rank (hierarchical level) of the item. If the specified } \\
\text { field is not numeric then its numeric value is found in } \\
\text { the RankTable. }\end{array}$ \\
\hline
\end{tabular}




\begin{tabular}{|c|c|c|c|c|}
\hline DIXSEQFIELD & Text & 50 & & $\begin{array}{l}\text { DixSeqField: the name of the field that provides a } \\
\text { sorting scheme for the dictionary: the items of the } \\
\text { dictionary are sorted on this column. }\end{array}$ \\
\hline TREETABLE & Text & 50 & & $\begin{array}{l}\text { TreeTable: the name of the table that organizes the } \\
\text { lookup table (DixTable) into a hierarchy. }\end{array}$ \\
\hline TREEPARENT & Text & 50 & & $\begin{array}{l}\text { TreeParent: the name of the field containing the } \\
\text { parent item. }\end{array}$ \\
\hline TREECHILD & Text & 50 & & $\begin{array}{l}\text { TreeChild: the name of the field containing the child } \\
\text { item }\end{array}$ \\
\hline RANKTABLE & Text & 50 & & $\begin{array}{l}\text { RankTable: the name of the table that provides } \\
\text { numeric values for qualitative ranks }\end{array}$ \\
\hline RANKFIELD & Text & 50 & & $\begin{array}{l}\text { RankField: the name of the field that contains the } \\
\text { qualitative rank name and which corresponds with } \\
\text { the DixRankField. }\end{array}$ \\
\hline RANKVALUE & Text & 50 & & $\begin{array}{l}\text { RankValue: the name of the field in the RankTable } \\
\text { that contains the numeric rank value. }\end{array}$ \\
\hline SYSKEY & Table & $\mathrm{N} / \mathrm{A}$ & $\begin{array}{l}\text { System table used by } \\
\text { GeoMatter }\end{array}$ & $\begin{array}{l}\text { SYSKEY manages the incrementing of key } \\
\text { attributes; upon insertion of a new record in a table, } \\
\text { SYSKEY is consulted for the next key value. }\end{array}$ \\
\hline KEYTABLE & Text & 50 & & The name of the table containing the key attribute. \\
\hline KEYFIELD & Text & 50 & & The name of the field containing the key attribute. \\
\hline LASTKEY & $\begin{array}{l}\text { Long } \\
\text { Integer }\end{array}$ & 4 & & The last value used in the key field. \\
\hline
\end{tabular}

Table 2: Description of queries contained in the database for this report

\begin{tabular}{|c|c|c|c|}
\hline Name & Type & Width & Description \\
\hline QryAcidBuff & Query & $\mathrm{N} / \mathrm{A}$ & $\begin{array}{l}\text { A composite query that assembles the queries } \\
\text { 'QryPrimLithologyCarb' and 'QrySecLithologyCarb' resulting in a } \\
\text { single query that contains COA_ID's that have a carbonate rock in } \\
\text { either a primary component or secondary (all other amounts beside } \\
\text { primary). The type of carbonate is specified in the primary_lith and } \\
\text { second_lith fields }\end{array}$ \\
\hline coa_id & $\begin{array}{l}\text { Long } \\
\text { Integer }\end{array}$ & 4 & $\begin{array}{l}\text { Unique identification number of a unit in the Compound Object } \\
\text { Archive }\end{array}$ \\
\hline coa_name & Text & 50 & The name of the unit in the Compound Object Archive \\
\hline Primary_lith & Text & 50 & $\begin{array}{l}\text { A lithologic classification term selected from those available in the } \\
\text { Lithology Table }\end{array}$ \\
\hline second_lith & Text & 50 & $\begin{array}{l}\text { A lithologic classification term selected from those available in the } \\
\text { Lithology Table }\end{array}$ \\
\hline QryCarbAndMuds & Query & $\mathrm{N} / \mathrm{A}$ & $\begin{array}{l}\text { Returns COA's that contain any amount of carbonate AND } \\
\text { mudstone in the same unit. Generalizes lithologies to include } \\
\text { specific type of carbonates and mudstones }\end{array}$ \\
\hline coa_id & $\begin{array}{l}\text { Long } \\
\text { Integer }\end{array}$ & 4 & $\begin{array}{l}\text { Unique identification number of a unit in the Compound Object } \\
\text { Archive }\end{array}$ \\
\hline coa_name & Text & 50 & The name of the unit in the Compound Object Archive \\
\hline
\end{tabular}




\begin{tabular}{|c|c|c|c|}
\hline QryCarbAndMudsAge & Query & $\mathrm{N} / \mathrm{A}$ & $\begin{array}{l}\text { Returns COA's that contain any amount of carbonate AND } \\
\text { mudstone in the same unit, along with the Minimum age of that } \\
\text { unit. Generalizes lithologies to include specific type of carbonates } \\
\text { and mudstones }\end{array}$ \\
\hline coa_id & $\begin{array}{l}\text { Long } \\
\text { Integer }\end{array}$ & 4 & $\begin{array}{l}\text { Unique identification number of a unit in the Compound Object } \\
\text { Archive }\end{array}$ \\
\hline coa_name & Text & 50 & The name of the unit in the Compound Object Archive \\
\hline age_name & Text & 50 & $\begin{array}{l}\text { The minimum time-stratigraphic age selected from the Stratigraphic } \\
\text { Time Scale Table }\end{array}$ \\
\hline min_age & Double & 8 & Minimum numerical age, in millions of years \\
\hline QryCarbonates & Query & N/A & $\begin{array}{l}\text { Selects COA's with any amount of a carbonate (limestone or } \\
\text { dolomite) }\end{array}$ \\
\hline coa_id & $\begin{array}{l}\text { Long } \\
\text { Integer }\end{array}$ & 4 & $\begin{array}{l}\text { Unique identification number of a unit in the Compound Object } \\
\text { Archive }\end{array}$ \\
\hline coa_name & Text & 50 & The name of the unit in the Compound Object Archive \\
\hline QryGenToLith & Query & $\mathrm{N} / \mathrm{A}$ & $\begin{array}{l}\text { Selects the Primary lithology from a COA and traverses the } \\
\text { Lithology_Tree for all parent lithologies. Returns multiple records } \\
\text { for each lithology in a COA, depending on what the hierarchy level. } \\
\text { Returns the lith_level so that it may be selected on for a specific } \\
\text { lithology detail }\end{array}$ \\
\hline coa_id & $\begin{array}{l}\text { Long } \\
\text { Integer }\end{array}$ & 4 & $\begin{array}{l}\text { Unique identification number of a unit in the Compound Object } \\
\text { Archive }\end{array}$ \\
\hline lith_class & Text & 255 & $\begin{array}{l}\text { A predefined hierarchical list of lithologic terms used for classifying } \\
\text { rock compositions. }\end{array}$ \\
\hline lithology & Text & 255 & $\begin{array}{l}\text { A predefined hierarchical list of lithologic terms used for classifying } \\
\text { rock compositions. }\end{array}$ \\
\hline lith_level & $\begin{array}{l}\text { Long } \\
\text { Integer }\end{array}$ & 4 & A numeric value for the level in the hierarchy of lithologic terms. \\
\hline QryGenToMaxEon & Query & $\mathrm{N} / \mathrm{A}$ & $\begin{array}{l}\text { Selects COAs from the Stratigraphic_Age table and traverses the } \\
\text { Stratigraphic_Time_Scale hierarchy for a Maximum parent age with } \\
\text { a rank of 'eon' }\end{array}$ \\
\hline coa_id & $\begin{array}{l}\text { Long } \\
\text { Integer }\end{array}$ & 4 & $\begin{array}{l}\text { Unique identification number of a unit in the Compound Object } \\
\text { Archive }\end{array}$ \\
\hline min_age & Text & 50 & $\begin{array}{l}\text { The minimum time-stratigraphic age selected from the Stratigraphic } \\
\text { Time Scale Table }\end{array}$ \\
\hline max_age & Text & 50 & $\begin{array}{l}\text { The maximum time-stratigraphic age selected from the } \\
\text { Stratigraphic Time Scale Table }\end{array}$ \\
\hline max_parent_age & Text & 255 & The time-stratigraphic name for the time interval \\
\hline QryGenToMaxEpoch & Query & $\mathrm{N} / \mathrm{A}$ & $\begin{array}{l}\text { Selects COAs from the Stratigraphic_Age table and traverses the } \\
\text { Stratigraphic_Time_Scale hierarchy for a Maximum parent age with } \\
\text { a rank of 'epoch' }\end{array}$ \\
\hline coa_id & $\begin{array}{l}\text { Long } \\
\text { Integer }\end{array}$ & 4 & $\begin{array}{l}\text { Unique identification number of a unit in the Compound Object } \\
\text { Archive }\end{array}$ \\
\hline
\end{tabular}




\begin{tabular}{|c|c|c|c|}
\hline min_age & Text & 50 & $\begin{array}{l}\text { The minimum time-stratigraphic age selected from the Stratigraphic } \\
\text { Time Scale Table }\end{array}$ \\
\hline max_age & Text & 50 & $\begin{array}{l}\text { The maximum time-stratigraphic age selected from the } \\
\text { Stratigraphic Time Scale Table }\end{array}$ \\
\hline max_parent_age & Text & 255 & The time-stratigraphic name for the time interval \\
\hline QryGenToMaxEra & Query & N/A & $\begin{array}{l}\text { Selects COAs from the Stratigraphic_Age table and traverses the } \\
\text { Stratigraphic_Time_Scale hierarchy for a Maximum parent age with } \\
\text { a rank of 'era' }\end{array}$ \\
\hline coa_id & $\begin{array}{l}\text { Long } \\
\text { Integer }\end{array}$ & 4 & $\begin{array}{l}\text { Unique identification number of a unit in the Compound Object } \\
\text { Archive }\end{array}$ \\
\hline min_age & Text & 50 & $\begin{array}{l}\text { The minimum time-stratigraphic age selected from the Stratigraphic } \\
\text { Time Scale Table }\end{array}$ \\
\hline max_age & Text & 50 & $\begin{array}{l}\text { The maximum time-stratigraphic age selected from the } \\
\text { Stratigraphic Time Scale Table }\end{array}$ \\
\hline max_parent_age & Text & 255 & The time-stratigraphic name for the time interval \\
\hline QryGenToMaxPeriod & Query & N/A & $\begin{array}{l}\text { Selects COAs from the Stratigraphic_Age table and traverses the } \\
\text { Stratigraphic_Time_Scale hierarchy for a Maximum parent age with } \\
\text { a rank of 'period' }\end{array}$ \\
\hline coa_id & $\begin{array}{l}\text { Long } \\
\text { Integer }\end{array}$ & 4 & $\begin{array}{l}\text { Unique identification number of a unit in the Compound Object } \\
\text { Archive }\end{array}$ \\
\hline min_age & Text & 50 & $\begin{array}{l}\text { The minimum time-stratigraphic age selected from the Stratigraphic } \\
\text { Time Scale Table }\end{array}$ \\
\hline max_age & Text & 50 & $\begin{array}{l}\text { The maximum time-stratigraphic age selected from the } \\
\text { Stratigraphic Time Scale Table }\end{array}$ \\
\hline max_parent_age & Text & 255 & The time-stratigraphic name for the time interval \\
\hline QryGenToMaxSubperiod & Query & N/A & $\begin{array}{l}\text { Selects COAs from the Stratigraphic_Age table and traverses the } \\
\text { Stratigraphic_Time_Scale hierarchy for a Maximum parent age with } \\
\text { a rank of 'subperiod' }\end{array}$ \\
\hline coa_id & $\begin{array}{l}\text { Long } \\
\text { Integer }\end{array}$ & 4 & $\begin{array}{l}\text { Unique identification number of a unit in the Compound Object } \\
\text { Archive }\end{array}$ \\
\hline min_age & Text & 50 & $\begin{array}{l}\text { The minimum time-stratigraphic age selected from the Stratigraphic } \\
\text { Time Scale Table }\end{array}$ \\
\hline max_age & Text & 50 & $\begin{array}{l}\text { The maximum time-stratigraphic age selected from the } \\
\text { Stratigraphic Time Scale Table }\end{array}$ \\
\hline max_parent_age & Text & 255 & The time-stratigraphic name for the time interval \\
\hline QryGenToMinEon & Query & N/A & $\begin{array}{l}\text { Selects COAs from the Stratigraphic_Age table and traverses the } \\
\text { Stratigraphic_Time_Scale hierarchy for a Minimum parent age with } \\
\text { a rank of 'eon' }\end{array}$ \\
\hline coa_id & $\begin{array}{l}\text { Long } \\
\text { Integer }\end{array}$ & 4 & $\begin{array}{l}\text { Unique identification number of a unit in the Compound Object } \\
\text { Archive }\end{array}$ \\
\hline min_age & Text & 50 & $\begin{array}{l}\text { The minimum time-stratigraphic age selected from the Stratigraphic } \\
\text { Time Scale Table }\end{array}$ \\
\hline max_age & Text & 50 & $\begin{array}{l}\text { The maximum time-stratigraphic age selected from the } \\
\text { Stratigraphic Time Scale Table }\end{array}$ \\
\hline min_parent_age & Text & 255 & The time-stratigraphic name for the time interval \\
\hline
\end{tabular}




\begin{tabular}{|c|c|c|c|}
\hline QryGenToMinEpoch & Query & $\mathrm{N} / \mathrm{A}$ & $\begin{array}{l}\text { Selects COAs from the Stratigraphic_Age table and traverses the } \\
\text { Stratigraphic_Time_Scale hierarchy for a Minimum parent age with } \\
\text { a rank of 'epoch' }\end{array}$ \\
\hline coa_id & $\begin{array}{l}\text { Long } \\
\text { Integer }\end{array}$ & 4 & $\begin{array}{l}\text { Unique identification number of a unit in the Compound Object } \\
\text { Archive }\end{array}$ \\
\hline min_age & Text & 50 & $\begin{array}{l}\text { The minimum time-stratigraphic age selected from the Stratigraphic } \\
\text { Time Scale Table }\end{array}$ \\
\hline max_age & Text & 50 & $\begin{array}{l}\text { The maximum time-stratigraphic age selected from the } \\
\text { Stratigraphic Time Scale Table }\end{array}$ \\
\hline min_parent_age & Text & 255 & The time-stratigraphic name for the time interval \\
\hline QryGenToMinEra & Query & $\mathrm{N} / \mathrm{A}$ & $\begin{array}{l}\text { Selects COAs from the Stratigraphic_Age table and traverses the } \\
\text { Stratigraphic_Time_Scale hierarchy for a Minimum parent age with } \\
\text { a rank of 'era' }\end{array}$ \\
\hline coa_id & $\begin{array}{l}\text { Long } \\
\text { Integer }\end{array}$ & 4 & $\begin{array}{l}\text { Unique identification number of a unit in the Compound Object } \\
\text { Archive }\end{array}$ \\
\hline min_age & Text & 50 & $\begin{array}{l}\text { The minimum time-stratigraphic age selected from the Stratigraphic } \\
\text { Time Scale Table }\end{array}$ \\
\hline max_age & Text & 50 & $\begin{array}{l}\text { The maximum time-stratigraphic age selected from the } \\
\text { Stratigraphic Time Scale Table }\end{array}$ \\
\hline min_parent_age & Text & 255 & The time-stratigraphic name for the time interval \\
\hline QryGenToMinPeriod & Query & $\mathrm{N} / \mathrm{A}$ & $\begin{array}{l}\text { Selects COAs from the Stratigraphic_Age table and traverses the } \\
\text { Stratigraphic_Time_Scale hierarchy for a Minimum parent age with } \\
\text { a rank of 'period' }\end{array}$ \\
\hline coa_id & $\begin{array}{l}\text { Long } \\
\text { Integer }\end{array}$ & 4 & $\begin{array}{l}\text { Unique identification number of a unit in the Compound Object } \\
\text { Archive }\end{array}$ \\
\hline min_age & Text & 50 & $\begin{array}{l}\text { The minimum time-stratigraphic age selected from the Stratigraphic } \\
\text { Time Scale Table }\end{array}$ \\
\hline max_age & Text & 50 & $\begin{array}{l}\text { The maximum time-stratigraphic age selected from the } \\
\text { Stratigraphic Time Scale Table }\end{array}$ \\
\hline min_parent_age & Text & 255 & The time-stratigraphic name for the time interval \\
\hline QryGenToMinSubperiod & Query & $\mathrm{N} / \mathrm{A}$ & $\begin{array}{l}\text { Selects COAs from the Stratigraphic_Age table and traverses the } \\
\text { Stratigraphic_Time_Scale hierarchy for a Minimum parent age with } \\
\text { a rank of 'subperiod' }\end{array}$ \\
\hline coa_id & $\begin{array}{l}\text { Long } \\
\text { Integer }\end{array}$ & 4 & $\begin{array}{l}\text { Unique identification number of a unit in the Compound Object } \\
\text { Archive }\end{array}$ \\
\hline min_age & Text & 50 & $\begin{array}{l}\text { The minimum time-stratigraphic age selected from the Stratigraphic } \\
\text { Time Scale Table }\end{array}$ \\
\hline max_age & Text & 50 & $\begin{array}{l}\text { The maximum time-stratigraphic age selected from the } \\
\text { Stratigraphic Time Scale Table }\end{array}$ \\
\hline min_parent_age & Text & 255 & The time-stratigraphic name for the time interval \\
\hline QryGisRockPolyCOAID & Query & $\mathrm{N} / \mathrm{A}$ & $\begin{array}{l}\text { Traverses the Spatial_Classification, Classification_Object, } \\
\text { Data_Classification, and COA tables for all features that are } \\
\text { 'Rock_Unit' COA types }\end{array}$ \\
\hline
\end{tabular}




\begin{tabular}{|c|c|c|c|}
\hline spatial_obj_id & $\begin{array}{l}\text { Long } \\
\text { Integer }\end{array}$ & 50 & A unique identifier for each object in an individual data set, or layer \\
\hline coa_id & $\begin{array}{l}\text { Long } \\
\text { Integer }\end{array}$ & 4 & $\begin{array}{l}\text { Unique identification number of a unit in the Compound Object } \\
\text { Archive }\end{array}$ \\
\hline QryIntrusiveCarbonates & Query & N/A & $\begin{array}{l}\text { Returns COA_ID's of all units that contain any amount of } \\
\text { Carbonate or Plutonic rock. Traverses the lithology_tree table to } \\
\text { generalize subtypes of carbonates and plutonics. Returns both the } \\
\text { rock type (lith_class) and the generalized type (parent_class) }\end{array}$ \\
\hline lith_class & Text & 255 & $\begin{array}{l}\text { A predefined hierarchical list of lithologic terms used for classifying } \\
\text { rock compositions. }\end{array}$ \\
\hline Parent_class & Text & 255 & $\begin{array}{l}\text { A predefined hierarchical list of lithologic terms used for classifying } \\
\text { rock compositions. }\end{array}$ \\
\hline coa_id & $\begin{array}{l}\text { Long } \\
\text { Integer }\end{array}$ & 4 & $\begin{array}{l}\text { Unique identification number of a unit in the Compound Object } \\
\text { Archive }\end{array}$ \\
\hline QryIntrusiveCarbonatesAge & Query & N/A & $\begin{array}{l}\text { Returns COA_ID's of all units that contain any amount of } \\
\text { Carbonate or Plutonic rock. Traverses the lithology_tree table to } \\
\text { generalize subtypes of carbonates and plutonics. Returns both the } \\
\text { rock type (lith_class) and the generalized type (parent_class). Also } \\
\text { returns Minimum and Maximum Age information for determining if a } \\
\text { carbonate predates a plutonic rock }\end{array}$ \\
\hline lith_class & Text & 255 & $\begin{array}{l}\text { A predefined hierarchical list of lithologic terms used for classifying } \\
\text { rock compositions. }\end{array}$ \\
\hline coa_name & Text & 50 & The name of the unit in the Compound Object Archive \\
\hline Parent_class & Text & 255 & $\begin{array}{l}\text { A predefined hierarchical list of lithologic terms used for classifying } \\
\text { rock compositions. }\end{array}$ \\
\hline coa_id & $\begin{array}{l}\text { Long } \\
\text { Integer }\end{array}$ & 4 & $\begin{array}{l}\text { Unique identification number of a unit in the Compound Object } \\
\text { Archive }\end{array}$ \\
\hline min_strat_name & Text & 50 & $\begin{array}{l}\text { The minimum time-stratigraphic age selected from the Stratigraphic } \\
\text { Time Scale Table }\end{array}$ \\
\hline max_strat_name & Text & 50 & $\begin{array}{l}\text { The maximum time-stratigraphic age selected from the } \\
\text { Stratigraphic Time Scale Table }\end{array}$ \\
\hline min_age & Double & 8 & Minimum numerical age, in millions of years \\
\hline max_age & Double & 8 & Maximum numerical age, in millions of years \\
\hline QryPrimLithologyCarb & Query & N/A & $\begin{array}{l}\text { Returns COA_ID's of all units that contain a carbonate in Primary } \\
\text { abundance. }\end{array}$ \\
\hline coa_id & $\begin{array}{l}\text { Long } \\
\text { Integer }\end{array}$ & 4 & $\begin{array}{l}\text { Unique identification number of a unit in the Compound Object } \\
\text { Archive }\end{array}$ \\
\hline comp_seq & $\begin{array}{l}\text { Long } \\
\text { Integer }\end{array}$ & 4 & $\begin{array}{l}\text { Unique ID number of a composition within a rock unit. Also } \\
\text { indicates the sequence number for displaying descriptive } \\
\text { information about this composition within a rock unit description. } \\
\text { Compositions are normally sequenced from most abundant to least } \\
\text { abundant }\end{array}$ \\
\hline lith_class & Text & 50 & $\begin{array}{l}\text { A lithologic classification term selected from those available in the } \\
\text { Lithology Table }\end{array}$ \\
\hline
\end{tabular}




\begin{tabular}{|l|c|c|l|}
\hline QrySecLithologyCarb & Query & N/A & $\begin{array}{l}\text { Returns COA_ID's of all units that contain a carbonate in any of the } \\
\text { Non-primary abundance. }\end{array}$ \\
\hline Coa_id & $\begin{array}{c}\text { Long } \\
\text { Integer }\end{array}$ & 4 & $\begin{array}{l}\text { Unique identification number of a unit in the Compound Object } \\
\text { Archive }\end{array}$ \\
\hline lith_class & Text & 50 & $\begin{array}{l}\text { A lithologic classification term selected from those available in the } \\
\text { Lithology Table }\end{array}$ \\
\hline
\end{tabular}

\section{References}

Hintze, L.F., 1980, Geologic map of Utah: Utah Geological and Mineral Survey, scale 1:500,000. 